\title{
Economic Reforms and Constitutional Transition
}

Jeffrey D. Sachs, Wing Thye Woo and Xiaokai Yang

CID Working Paper No. 43

April 2000

(C) Copyright 2000 Jeffrey D. Sachs, Wing Thye Woo and Xiaokai

Yang and the President and Fellows of Harvard College
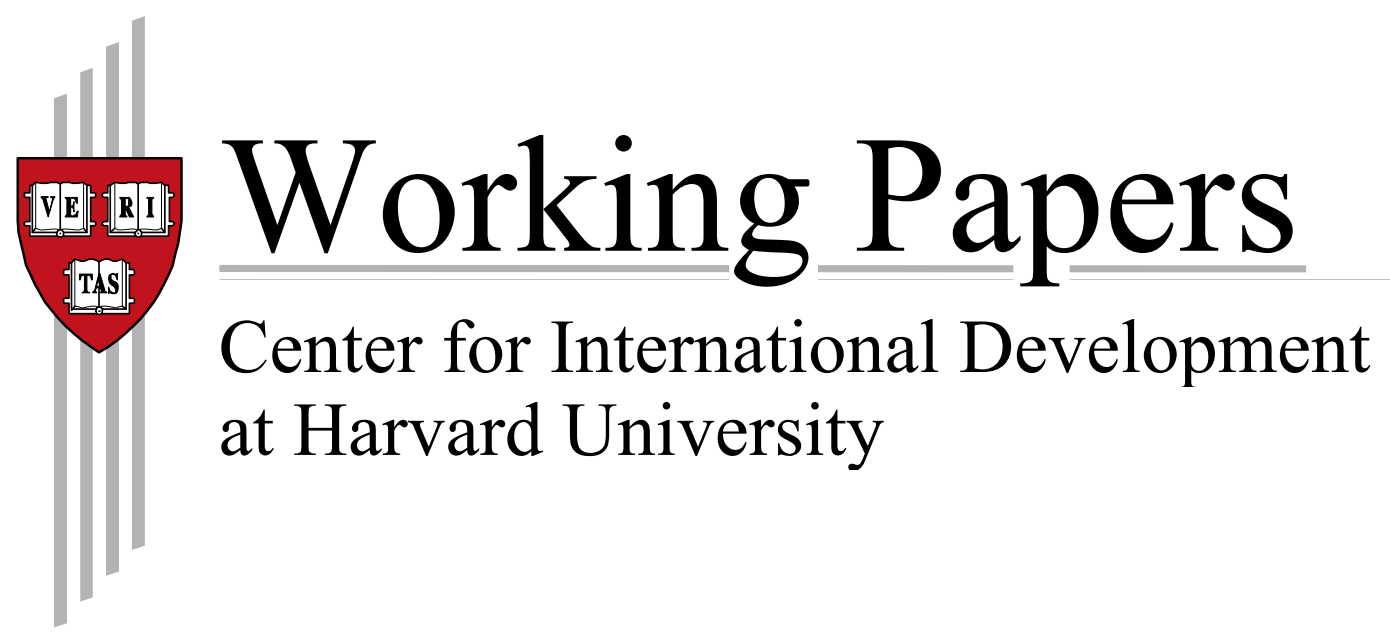


\title{
Economic Reforms and Constitutional Transition
}

\author{
Jeffrey Sachs, Wing Thye Woo and Xiaokai Yang
}

\begin{abstract}
This paper investigates the relationship between economic reforms and constitutional transition, which has been neglected by many transition economists. It is argued that assessment of reform performance might be very misleading if it is not recognized that economic reforms are just a small part of large scale of constitutional transition. Rivalry and competition between states and between political forces within each country are the driving forces for constitutional transition. We use Russia as an example of economic reforms associated with constitutional transition and China as an example of economic reforms in the absence of constitutional transition to examine features and problems in the two patterns of transition. It is concluded that under political monopoly of the ruling party, economic transition will be hijacked by state opportunism. Dual track approach to economic transition may generate very high long-term cost of constitutional transition that might well outweigh its short-term benefit of buying out the vested interests.
\end{abstract}

Keywords: constitutional transition, economic reform, division of labor, debate of shock therapy vs gradualism, debate of convergence vs institutional innovation

JEL Classification Codes: K1, H1, B14, M40, O10, P20

Jeffrey Sachs is Director of the Center for International Development (CID) and Galen L. Stone Professor of International Trade at the Department of Economics at Harvard University.

Wing Thye Woo is Professor, Department of Economics, at the University of California at Davis.

Xiaokai Yang is Personal Chair Professor, Department of Economics, at Monash University and Research Fellow at the Center for International Development (CID) at Harvard University. 


\section{Understanding Economic Transition}

There are two major approaches to studying economic transition. One of them, surveyed by Dewatripont and Roland (1996), McMillan (1996), Blanchard (1997), Qian (1999), Maskin and Xu (1999), and Roland (2000), uses formal models of endogenous transaction costs to analyze economic transition. This approach explicitly spells out the assumptions and predictions and has all the advantages of the formal models. Its shortcoming is that most of the formal models are partial equilibrium models that cannot figure out the complex interplay between endogenous transaction costs and the network size of division of labor.

Also, the formal models are too simple to capture the complexity of institutional changes. The core of transition is a large-scale shift of constitutional rules (Sachs and Pistor 1997). Economic transition (i.e., price liberalization and privatization) is only part of the transition.

In a recent debate about relative merit of gradual versus shock therapy approaches to the transition, the gradualist view was overwhelmingly dominant (see Roland, 2000 and Sachs and Woo, 1999). This is partly due to the lack of constitutional thinking among economists. Some economists who are in favor of gradualism easily jump to the conclusions by looking only at the short-term economic effects of different approaches to the transition. To understand why this is not appropriate, we may raise the question: If the transition of constitutional rules in France in the $19^{\text {th }}$ century had been gradual, would the transition have been more successful and welfare improving?

There are three difficulties in answering the question. First, the long-term effects of the changes in the constitutional rules on economic performance are not always consistent with their short-term effects. It is not easy to distinguish one from another of the two. For instance, the formation of the constitutional order in France started in the French Revolution and lasted for about one century. The short-term effect of the French Revolution on the economy was disastrous (Beik, 1970). However, the Napoleonic Code and many other institutions and policies that emerged from the long transition process from the Old Regime to the new constitutional order might have had positive long-term effects on economic development in France. This transition, together with the rivalry between the UK, France, other European continental countries, and the US, generated the leap-frog of the Western Continental Europe's economic development over the UK in the second half of the $19^{\text {th }}$ century (Crafts, 1997). Also, the short-term economic effect of the American Independence War and American Civil War was very negative. But most historians would not deny the significantly positive long-term economic effects of the two transitions of constitutional rules.

The transition from the old regime to the new constitutional order may have significant short-term negative effects on economic development for at least two reasons. First, the transition must face the well-known dilemma of powerful and legitimate state violence being essential for protecting all individuals' rights (Barzel, 1997). According to Buchanan (1989), property rights emerge from the police's powerful (hence credible) and legitimate violence that can effectively enforce the penalty for theft. But such powerful state violence usually tends to violate rather than

\footnotetext{
${ }^{1}$ The negative short-term economic effect of the American Independence War is documented in Nettels (1962, p. 50), Nussbaum (1925), Taylower (1932), Philips (1929, pp. 115-19), Deane and Cole (1967, p. 48). The negative short-term economic effect of the American Civil War is documented in Woodward (1951, pp. 120-40).
} 
protect individuals' rights. Because of this dilemma, the short-term economic effects of the changes of constitutional rules on economic development are more likely to be negative. Second, it takes a long time to build up players' confidence in game rules. When changes in game rules occur during the transition, the lack of credibility of the new rules could create social disorder and have adverse effects on economic development.

The second difficulty in answering the above question relates to the trade off between the smooth buyout provided by gradualism and state opportunism institutionalized by the dual track approach that is associated with gradualism (Roland, 2000, p.43, and Cheung, 1996). It is not easy to identify the efficient balance of the trade off, which might be different for different countries. The transition to a fair, transparent, stable and certain constitutional rules is incompatible with the dual track approach, which features arbitrary and discretionary government power and unfair, unstable, uncertain, and nontransparent game rules. The former requires the credible commitment of the government to the game rules, while the latter is characterized by non-credibility of the government's commitment to the fair rules. Also, the dual track approach institutionalizes the arrangements wherein the government officials are the rule maker, the rule enforcer, the referee, and the player at the same time. This is incompatible with the constitutional principle that they must be separated (see sections 4 and 5).

If economic development is a process in which many countries conduct social experiments with various institutions in a long period of time in order to find the institutions that promote economic development, then some countries happen to be associated with an evolutionary process toward the efficient institutions and others happen to experiment with the inefficient ones. For the former, economic transition would be associated with gradual evolution of institutions. But for the latter, the inefficient institutions, old game rules, and related tradition must be discontinued and new game rules and new tradition must be created and consolidated. This transition needs big bang to establish credible commitment by major players to giving up old game rules.

The third difficulty in answering the question raised above involves the comparison of total discounted welfare between different generations of individuals. The French Revolution intensifies the rivalry between French continental culture and British common law tradition. This might increase the generic diversity of institutional experiments and create more opportunities for welfare improvement in human society. Certainly, if such benefit exists, it goes to the younger generations in many countries at the cost of the older generations in France. Similarly, the US's Independence War increased the genetic diversity of institutions and culture within the Anglo-Saxon tradition, thereby increasing the welfare of young generations at the expense of the old ones. But we economists have no consensus about how to efficiently trade off one generation's welfare against the other generation's.

Finally, the transition of constitutional rules usually involves many stages. It is very difficult, if not impossible, to analyze the complete effects of a single stage of transition. For instance, the French Revolution had very negative immediate impact on France's economic development. It did, however, clear the way for Napoleon's bigbang transition to the new constitutional rules based on the Napoleonic Codes and equality of all men before the law, which had positive effects on France's economic development. Mao's experiments with administrative decentralization in the absence of markets and private property rights in the 1960s and early 1970s were disastrous for China's economic development. But they generated a big shock to the central 
planning in China and cleared the way for Deng's regional decentralization and other market-oriented reforms.

According to Mokyr (1990), the rivalry between Britain and France was an important driving force of the big bang transition of French institutions during and after the French Revolution. According to Yang (1994), the rivalry between Chinese and Russian communists was an important driving force of Mao's big shock to the central planning system in 1960 and 1970 China. Hence, it is more important to investigate the driving mechanism than to investigate the short-term economic effects of one of the many stages of transition of constitutional rules.

Recently, many models of the commitment game have been used to show why, in the short-run, the dual track approach can work in China in the absence of the credible commitment mechanism to constitutional order (Qian 1999). But it is much more important to use the commitment game models to formalize North and Weingast's (1989) ideas about why the credible commitment mechanism to constitutional order is essential for long-term economic development.

This may need evolutionary game models with information problems to explain the endogenous evolution of game rules associated with institutional changes and constitutional transition. But so far, no such models are available. The existing evolutionary game models can only explain the evolution of strategies, but not that of game rules. We cannot even predict the emergence of the simple game rule that penalizes theft via criminal laws, the judiciary system, and the police. Perhaps, evolutionary game models that formalize economics of state, developed by Barzel (1997), and economics of constitution, developed by Buchanan (1989), can finally provide some tools of the trade for the economics of transition. But before that, formal models of economic transition might play a quite limited role in policy making. They are too simple and too specific to be close to real complex large scale of institutional changes.

Hence, another approach to the economics of transition that involves no formal models has so far been very influential in policy making. This line of research includes the meticulous documentation of changes of institutions and policies and their economic consequences, represented by Lardy (1998), and the descriptive analysis of policy and history, represented by North (1997), North and Weingast (1989), Qian and Weingast (1997), Sachs (1993), and Sachs and Woo (1999).

In this paper, we shall combine the two approaches to study transition economics. We will use the inframarginal analysis of the network of division of labor to investigate economic transition. When formal models are too simple to capture the complexity of institutional evolution, we will combine this inframarginal analysis with insights from constitutional economics, new economic history school, and the economics of state to address problems in economic transition.

Sections 2 and 3 discuss how to use the Smithian models covered in Sachs and Yang (2000) to investigate the features of the Soviet style socialist system and the driving mechanism for economic transition. Sections 4 and 5 examine the relationship between market-oriented reforms and the transition of constitutional rules. Section 6

\footnotetext{
2 The debate between gradualism and shock therapy has a long history since the debate between Edmund Burke (1790) and French revolutionaries. Olson (1982) was a recent supporter of big bang institutional transition. He argued that a stable constitutional order institutionalizes rent seeking and big bang to the existing order can break institutionalized rent seeking. Hayek $(1945,1960)$ was a recent supporter of Burke's view of spontaneous order and gradual evolution of institutions. It might be fair to say that the coexistence of British gradualism and French big bang is better than any one of them alone.
} 
uses some formal models to analyze some transition phenomena, such as large scale output fall and financial crisis.

\section{The Socialist System and Evolution in Division of Labor}

In order to understand economic transition, we have to first address the following questions: Why has the Soviet style socialist system finally been rejected by most countries that adopted it? Why could such a system survive, spread, and even achieve short-run impressive growth performance before it was finally rejected? The second question relates to the question: What are the characteristics of the Soviet style economic system? In this section we shall address the three questions. We then draw the distinction between the Soviet style socialist system, Mao's socialist system, and Deng's socialist market system. The distinction can then be used to explain the differences in transition pattern between China, Russia, and East Europe.

The debate between Lange, von Mises, and Hayek relates to the first question. von Mises (1922) and Hayek (1940) believed that the Soviet style economic system will fail to work since it cannot obtain necessary information in the absence of the market. They argued that the calculation cost for working out an internally consistent plan is too high to be feasible. Lange and Taylor (1964) used the neoclassical general equilibrium model to argue that market socialism can solve the problem of a prohibitively high calculation cost of the economic plan. Under market socialism, markets for consumption goods are allowed, but all firms and production means are owned by the state. The central planner commands the managers of all state firms to maximize the profit for given prices and report the profit maximizing quantities to him. Then he adjusts market prices according to excess demand until the markets for consumption goods are cleared. They believed that market socialism could allocate resources more efficiently than a capitalist system. Hayek (1988) and Friedman (1962) disagree. According to them, the central planner has no incentive to adjust prices to clear the market, and the managers of state firms have no incentive to maximize profit in the absence of private ownership of firms. Instead, the central planner has all reasons to keep positive excess demand, which can generate planning power and a great deal of tangible and intangible benefit for him.

According to Kornai $(1980,1992)$, managers will not maximize profit and will not respond to changes of prices if the budget constraint is soft. The managers have all reasons to understate production capacity and overstate input requirement, so that prices cannot convey real information in the absence of private ownership of firms and factors. Hence, disequilibrium becomes chronic and resource allocation is distorted.

Some Chinese economists have developed several theories of the Soviet style economic system in the 1980s. One of them is referred to as the theory of absence of ownership. Several papers by Hua Sheng, Zhang Xuejuen, and Lo Xiaopen (1988), Yi Gang (1988), Ping Xinqiao (1988), and Men Qinguo (1988) almost simultaneously proposed a theory of absence of ownership. This theory states that the state ownership system is used to purposely divide different components of ownership of the same property between separate institutions. According to the definition of ownership in the economics of property rights, ownership consists of two components: exclusive rights to disposal of property and exclusive rights to bearing (positive or negative) earnings from

property (see Furubotn and Pejovich, 1974). In a socialist economy, rights to disposal of property are divided among the planning committee, the price bureau, the labor bureau, the government industrial departments, and managers of enterprises. The planning 
committee has a say on long-run investment and related resource allocation; the price bureau has a say on pricing; the labor bureau has a say on the assignment of personnel; the government industrial departments have a say on intermediate term investments and the allocation of crucial goods and input factors; the managers have a say on daily managerial decisions. Rights to collecting revenue or enduring losses, another component of ownership, are divided between the finance ministry and the industrial ministries. Hence, no single individual or institution has complete ownership of a single piece of state-owned property. The Chinese call this "a system without a real boss," or "a system with an absence of ownership." It was argued that any decentralization and liberalization reform of such a system in the absence of any substantive change in property right structure will create more problems than it solves.

One of these articles (Men Qiuguo, 1988) points to the fact that such division of different components of ownership between separate institutions is a necessary sin if there are no private property rights in place. Such an institutional arrangement mimics a control system in modern corporations. It is a sort of check-and-balance mechanism. This check-and-balance system, along with substantial privileges for the top officials provides an effective control system, as well as incentives to manage this system. Zhang (1986, 1999) proposed several important propositions to highlight essential rule of privatization in economic reforms. The major of them are several impossibility claims under the state ownership system of firms: "it is impossible to have entrepreneurship; it is impossible to separate firms from state; it is impossible to constrain managers' behavior via bankruptcy; it is impossible to efficiently march management with firms under the state joint stock ownership system." He claims that the bureau of state assets is a second government which is unable to efficiently manage state assets if the original government cannot do it.

Cheung (1974) and Shleifer and Vishny $(1992,1993)$ develop two theories of price control. The theories are quite relevant to the theory of the Soviet style economic system. According to Cheung's theory, price control can be used to create rents, which are the difference between the official price and the market equilibrium price. Competition for the rents will create a possible social disorder that cannot stop until the rents have been dissipated. The threat to social order calls for a hierarchical social structure, which distributes rents according to individuals' social status. The hierarchy is used by the privileged class to pursue their interests at the cost of society. The theory could mean that shortage is purposely created (perhaps in the subconscious of officials) to justify a hierarchical social order. Shleifer and Vishny's theory of pervasive shortages under socialism implies that shortage is a way for government officials to extract monopoly rents, which is better than a direct monopoly price because it can be used to cover up monopoly profit, thereby reducing public resentment against monopoly rent. The theories can be used to invalidate Lange's theory of market socialism. According to Cheung and Shleifer and Vishny's theories, if the government's purpose is to make use of the shortage to justify its monopoly power in a hierarchical social structure, how can we expect it to adjust prices according to excess demand?

The debate generates the conclusion that market socialism cannot work. ${ }^{3}$ Hungary's experiment with market socialism verifies this conclusion (see Kornai, 1986). However, this conclusion has not addressed our second question. The Soviet Union did not adopt market socialism in the 1930s and 1950s. But not only did its central planning system survive, but it was also diffused to many countries after WWII. It had achieved average real GDP growth rates of 8\% in 1933-1940 and of 9.4 in 1948-1958, as impressive as

\footnotetext{
${ }^{3}$ Recent criticisms of and defenses for market socialism can be found from Bardhan and Roemer (eds.) (1993).
} 
China's growth rates in the reform era. Why could von Mises and Hayek (1944) not predict the short-run impressive growth performance of the Soviet style economic system, despite their correct prediction of the long-run failure of this system? Kornai's theory of socialism and von Mises, Hayek, Friedman, Cheung, and Shleifer's analysis of socialism have not addressed the question. The answer to this question relates to the ongoing debate about shock therapy and gradualism.

Sachs (1994), Sachs and Woo (1994), and Yang (1994) provide an answer to this question. We shall now outline this answer, which is based on the development theories generated by Smithian models of division of labor.

As shown in the Smithian models in the Sachs and Yang (2000), economic development is a process with evolution in division of labor. In particular, $\mathrm{Ng}$ and Yang (1997, see Sachs and Yang, 2000, chapter 15) shows that in a world of bounded rationality, the evolution of division of labor is determined by the interplay between organization information acquired by society via experiments with various patterns of division of labor and individuals' dynamic decisions on the experiment patterns. The trade offs between the information gains generated by social experiments and experiment costs, and between economies of division of labor and transaction costs, imply that more patterns of division of labor will be experimented with and more organization information will be acquired via the market, the higher the experiment and trading efficiency. Since society can only gradually learn the information about the efficient pattern of division of labor, those simple patterns of division of labor are experimented with before are the complex ones when individuals are short of organization information. This implies that economic development involves a gradual evolutionary process from the simple pattern of division of labor to the increasingly more complex ones.

As shown in Ng and Yang (1997, see also Sachs and Yang, 2000, chapter 15), however, the latecomers of economic development can mimic the efficient pattern of division of labor by jumping over many intermediate levels of division of labor if the developed countries have already found the efficient pattern by gradual social experiments. The capitalist institutions in the developed countries were conducive to a great variety of patterns of division of labor to have been experimented with by the market. The free organization information created by capitalist developed countries creates an opportunity for big push industrialization for the latecomers. It is possible that big push industrialization can be carried out by a Soviet style socialist system that has no institutional infrastructure that is essential for discovering the efficient pattern of industrialization. This possibility for big push industrialization via the imitation of the industrial pattern created by capitalist institutions in the absence of the capitalist institutional infrastructure is the rationale for relatively successful industrialization in the Soviet style socialist countries in the 1930s and 1950s. It is by ignoring this possibility that Hayek and von Mises failed to predict the survival, spread, and impressive growth performance of the Soviet style economic system in the middle of the $20^{\text {th }}$ century.

To address the third question, we briefly outline the characteristics of the Soviet style socialist system as follows.

\footnotetext{
${ }^{4}$ See Mitchell $(1998$, pp. 912, 919) for the growth rates in terms of constant prices in the Russia during the two periods. This was a surprise to von Mises and Hayek. Because of this impressive growth performance, Samuelson and many other economists could not even sense the pending fall of the Soviet economic system when the disintegration of the Soviet Union was about to occur (see Skousen, 1997).
} 
(1) By keeping a low relative price of agricultural to industrial goods and controlling all firms, this system used state ownership of all firms and central planning to achieve a high profit margin of the state industrial sector. The profit of state firms was allocated to mimic the high saving and investment rates and a growth rate of the heavy industrial sector that is higher than in the light industrial sector. This pattern of industrial development was created by the capitalist industrialization process. In terms of the Smithian model in Shi and Yang (1995, see also Sachs and Yang, 2000, chapter 12), the higher growth rates of the heavy industrial sector are generated by the increases in production roundaboutness and in the income share of the sector producing producer goods, which are one aspect of the evolution in division of labor.

(2) State ownership of firms and a central planning system were used to organize comprehensive industrial investment programs, which simultaneously created many very specialized industrial firms when the markets for a great variety of industrial goods were absent. This kind of comprehensive state investment program generated a big jump of the network size of division of labor, which implies a jump of variety of highly specialized industrial sectors. In the Soviet Union in the 1930s, this kind of comprehensive state industrial investment plan was worked out by hiring many experts from capitalist developed countries (Zaleski, 1980). In China in the 1950s, this was achieved with the assistance of experts from the Soviet Union and East Europe. The comprehensive state investment programs quite effectively utilized free organization information about the efficient pattern of division of labor and industrial linkage network effects of division of labor. A specific case of such programs is China's program of 694 large projects and 156 Soviet Union-aided key projects in the $1950 \mathrm{~s}$, which successfully created a large industrial network of division of labor among many highly specialized firms within a short period of time, when there was no market for those highly specialized producer goods (Zhou, 1984). For instance, a firm specializing in producing artificial diamonds used in the machine tools industry was established in Zhengzhou as one of the 156 key projects, with assistance from East Germany when demand for machine fools was not enough to support a large specialized firm making artificial diamonds.

(3) The central planning authorities quite systematically mimic industrial standardization, mass production, the production line, the mechanism of checks and balances between managers, treasurers, and accountants within a capitalist corporation, Taylor scientific management, and other organization patterns and management approaches developed by capitalist firms. A mechanism of checks and balances between industrial ministries, the ministry of finance, state banks, the planning committee, the pricing bureau, the bureau of material distribution, and other institutions was established by dividing rights to disposal and appropriation of the same properties among the institutions. This checks-and-balances mechanism established quite an effective control mechanism for the whole economy by the central planning authorities. Top government and party officials collectively claim the residual of the operation of the planning system, so that they have the incentive to run this system to maximize the residual. According to Lenin, the Soviet central

\footnotetext{
${ }^{5}$ Such state investment programs are quite consistent with the theory of big push industrialization discussed in Ng and Yang (1997) and Murphy, Shleifer, and Visiny (1989). The documentation of the mimicry of capitalist industrial pattern and big push industrialization in the Soviet Union can be found from Zaleski (1980). Lenin (1939) outlined his understanding of the features of capitalist industrialization, which Soviet planners mimic later on. The documentation of China's big push industrialization can be found from Fang (1984).
} 
planner should organize the whole economy as a large corporation. But on the top of the apparatus, there were no effective checks and balances. The monopoly in founding firms and in all sectors by the government and party apparatus is in sharp contrast to the constitutional order created in the UK in 1688 with free association (including automatic free registration of private firms) and an independent judiciary. That system establishes checks and balances on the top of the political arena. Hence, the Soviet style socialist system creates great room for institutionalized state opportunism.

(4) The central planning authorities used a set of material balance tables and an iterative procedure to match demand with supply of goods in the absence of markets for intermediate factors. The system can fairly well approximate the result generated by Leontief's input-output method. ${ }^{6}$ However, the Leontief input-output method cannot take into account the substitution between different inputs. It is incapable of sorting out the final demand for consumption goods and of providing an effective incentive mechanism for players to reveal private information. According to Roland (2000, chapter 1), the equilibrium that is achieved via a dynamic iterative process of the central planning is inefficient.

(5) However, the imitation of all successful patterns of industrialization and internal patterns of capitalist firms was realized by destroying the capitalist institutional infrastructure that generated the successful patterns of industrialization and organization in the capitalist developed economy. This is the first centralized social experiment with economic institutions. The precondition for a centralized social experiment is to establish monopoly power in the sector that designs system arrangements. This was realized through violent revolution, violent infringements upon private property rights, and "red terror" in the numerous purging campaigns. The lack of fair competition in the sector that designs institutional arrangements implies that the institutional arrangements that are chosen cannot be efficient. Also, the Soviet style socialist economic system is the first system that was purposely designed by a government rather than emerging from the spontaneous evolution and from interactions of players through fair competition and the voluntary trade of property rights. According to Hayek, efficient institutional arrangements can emerge only as a result of such fair competition and voluntary trade.

As Sachs (1994) suggests, the strategy of imitating the industrialization pattern of the capitalist developed economy, in the absence of a capitalist institutional infrastructure, can generate short-run impressive growth performance. However, as the potential for the imitation has been exhausted or as the network of division of labor becomes increasingly more complex, the long-run cost of this strategy will outweigh its short-run benefit since this system does not have an institutional infrastructure that can create its own capacity for economic development and institutional innovations.

More generally, when the latecomer to economic development tries to catch up to the developed country, it usually follows a reverse engineering of institutional development. It first tries to mimic the industrial pattern, then the economic institution,

\footnotetext{
${ }^{6}$ For the operation of the material balance process in a Soviet style economic system, World Bank (1984) provides detailed documentation.

${ }^{7}$ The early literature of the socialist economy focuses on feature (4) of the socialist system and has paid too little attention to features (2), (3), and (5). In fact, the comprehensive state investment program is much more important than balance of daily production plans in a socialist system. Kornai's theory of the soft budget constraint focuses on feature (5).

${ }^{8}$ Riskin (1987) and World Bank (1984) document the process to establish a Soviet style socialist system.
} 
such as the organization structure of private firms, then the legal system, such as corporation laws, then the political system, such as representative democracy. It may finally adopt some constitutional rules, such as checks and balances on power, and ideology and behavior norms from the developed countries. According to North (1994) and North and Weingast (1989), the original process of economic development in the UK was the other way around. Ideology and moral code determined the prevailing constitutional order, which determined the political system and legal system, which then generated a certain economic performance. In a geopolitical environment without an overarching political power in the international political arena, the economic performance difference between countries will generate pressure for changes in ideology and constitutional rules. North believes that changes in ideology and moral codes are much slower than changes in economic structure.

It should be noted that Mao's socialist system is substantially different from the Soviet style socialist system. Rivalry between Chinese and Russian communists created a sort of check-and-balance in the international political arena that involves the design of institutional arrangements. Hence, Mao's political instinct, which was sensitive to the rivalry, led him to create his administrative decentralization proposed in his 1956 speech "On Ten Important Relationships" (Mao, 1997a). The rivalry is the grand background from which the differences between the reforms in China and Russia emerge.

During the Great Leap Forward in 1958-1961 and the Cultural Revolution in 19661970, and since the Cultural Revolution, an effective central planning system has not existed in China. Five year plans and annual plans were virtually only on paper. The success of the first five-year plan in China in the 1950s misled Mao to conclude that the success was due to the merit of the socialist system that was created by communists. He did not understand that the success was based on Russians' imitation of the capitalist economy. Hence, Mao tried to invent his own communist institutions, such as the commune and mass eating halls. Also, Mao had a strong anti-Soviet Union sentiment. He advocated for administrative decentralization against central planning, for selfsufficiency of each firm, each county and each province against specialization and division of labor, for a mass line against professionism, for small scale, self-sufficient communes and brigade firms with indigenous technology against large-size state firms with advanced technology, and so on (see Mao, 1977b). This, on the one hand, slowed down the evolution of division of labor in China and kept rural China a traditional autarchic society. On the other hand, it created a vacuum in coordination mechanisms in Mao's China: neither central planning nor the market could coordinate the division of labor developed in the first five-year plan. This vacuum was filled by quasi-private firms and collective firms during the Cultural Revolution and by commune and brigade firms, which are later referred to as township and village enterprises (TVE) after 1984, and by a decentralized bilateral and multilateral bargaining system in the 1970s. Procurement fairs that implemented decentralized bargains were developed in the Mao era. Barters were very common in the fairs and sometimes commodities in short supply were used as commodity money.

\footnotetext{
${ }^{9}$ Qian (forthcoming) documents Mao's two administrative decentralization movements in 1958-1960 and in 1969-1975. Also, the features of the evolution of institutional arrangements from Mao's China to the reform era can be identified by putting information from the following sources together. Bruun (1993), Granick (1990), Liu (1992), Nee and Sijin (1993), Oi (1986), Perkings, ed. (1977), Riskin (1971, 1987), Schurmann (1968), Solinger (1992), Vogel (1989), Walder (1986, 1992a, b), Wank (1993), Wong (1985, 1986a, b).
} 
As the 1996 World Development Report on the transition economies indicates, "Despite the industrialization efforts of the 1950s and 1960s, China was very poor and largely rural at the start of its reforms. Agriculture employed 71 percent of the work force and was heavily taxed to support industry. Social safety nets extended only to the state sector - about 20 percent of the population. Poor infrastructure and an emphasis on local self-sufficiency led to low regional specialization and large numbers of small and medium-sized firms. The economy was far less centrally planned and administered than the Soviet economy. Local governments had greater power and developed considerable management capacity, preparing them for a more decentralized economy. Chinese industry also received subsidies, but crosssubsidization was less pervasive (than in the Soviet Union)." "Because the agricultural sector had been so heavily repressed, freeing it up had immediate payoffs. ... China thus started transition largely as a peasant agrarian economy and with far greater scope for reallocating labor than Russia." In the former Soviet Union, more than 85 percent of the workforce was in non-agricultural state enterprises, compared with around 18 percent of the workforce in China (Sachs and Woo, 1999, Table 6). Perhaps 99 percent of the labor force of the former Soviet Union (including the 14 percent of the labor force in state and collective farms) were entitled to an "iron rice bowl" under the Soviet system as of 1985 (see Cook, 1993, for extensive documentation of worker protections in the Soviet Union). Very high proportions of workers in the Eastern European economies enjoyed similar guarantees.

Yang, Wang and Wills (1992) have shown that rural China was quite an autarchic society until 1978. The degree of commercialization was .3 before 1978, although the first five-year plan developed a high level of division of labor in urban China by mimicking the pattern of Soviet Union's industrialization. This means that rural China could develop a high level of division of labor either via commercialization or via central planning. It is easy to develop a commercialized market system from a low level of division of labor. But it is extremely difficult to develop private property rights and related markets in an economy with a high level of division of labor which was developed through central planning. Reforms were easy in rural China because of a low level of division of labor. In contrast, reforms in urban China were more difficult because of a much higher level of division of labor there established via central planning (see Byrd, 1983, 1988, Byrd and Tidrick, 1987, Perkins, 1988, and Walder, 1989). However, it was much easier in China as a whole than in Russia because the central planning system was paralyzed during the Cultural Revolution. Also, Mao's industrial system was much more disintegrated and locally self-sufficient than the Soviet style socialist system.

If an economy has developed a high level of division of labor quite successfully through centralized big push industrialization, then the centralized planning system which is not good for long-term economic growth is embodied in the high level of division of labor which contributes to long-term economic growth. Since the sophisticated input and output interdependence generated by a large network size of division of labor is coordinated by the central planning system, it is extremely difficult to separate the dismantling process of the central planning from the malfunctioning of the coordination of a large network of division of labor. There is an inertia to use central planning to coordinate the high level of division of labor if reforms take place gradually. A big push or shock therapy may be necessary to cut off the central planning coordination mechanism from the high level of division of labor. In the process, paralysis of the input-output network might be inevitable because of the high risk of coordination failure in a large, highly interdependent network of division of labor. Put 
another way, a well developed central planning system can be dismantled only through shock therapy, since the system itself does not have the institutional infrastructure that is necessary for discovering the efficient institutional arrangements over the transitional period from the Soviet style socialist system back to a capitalist system.

China experienced the shock process during 1958-1961 and 1966-1970, when the central planning system was paralyzed by Mao's Great Leap Forward and the Cultural Revolution, and during 1971-1976, when Mao's policy of administrative decentralization prevailed. Mao's administrative decentralization divided the ownership of state firms among the central, provincial, and county governments and communes. In contrast, in the Soviet Union, there was a uniform ownership of all state firms. Deng's regional decentralization consolidated Mao's administrative decentralization by institutionalizing the fiscal relationship between the central and provincial governments. Government revenue from tax and state firm profit was divided between the central and provincial governments according a certain division rule. In the early stage of Deng's regional decentralization, a fixed amount of provincial government revenue was delivered to the central government. In the later stage, a fixed proportion of the tax revenue was delivered to the central government. A Chinese style fiscal federalism emerges from the evolution, which provides a driving force for China's reforms in the 1990s. This fiscal federalism separates tax categories and a collection institution of local governments from that of the central government, with help from the World Bank (Qian and Roland, 1998, Qian and Weingast, 1997, Li, Li, and Zhang, 1998). Deng's fiscal federalism is in striking contrast with the much more centralized fiscal relationship between the federal and local governments in Russia (Zhuravskaya, 1998 and Qian, 1999). This partly explains the difference in reform performance between China and Russia.

But contributions of Deng's regional decentralization and fiscal federalism to economic development should not be overstated. First, it fragments the market and promotes monopoly power of local state enterprises (Zhou, 1999, He, 1997, p. 206). In other words, Deng's regional decentralization inherits the bad sides of Mao's administrative decentralization, thereby retarding the formation of the integrated national market. Lardy (1998a, p. 204) uses the automobile sector to illustrate this point. Second, China's fiscal federalism is far away from the fiscal federalism in the US. A residential registration system which has been in place since 1954 greatly restricts the free mobility of labor and human capital. Despite recent reforms to this system, which allow migrants who have no permanent residence in large cities to obtain annually renewable temporary residency, the migrant's position in China's large cities is not as good as that of immigrants with green cards in the US. Migrants in China must pay much higher school fees for their children and a much higher price for housing than local permanent residents. In Beijing and other large cities, firms hiring migrants with no local permanent residency are heavily fined by the government. ${ }^{10}$ Finally, China has a very centralized appointment system for leading provincial government officers. The central government regularly rotates the officers between provinces to make sure that they are absolutely loyal to the central government when local interests are in conflict with that of the central government. Hence, when Deng purposely kept a weak central government for political reasons after 1989, the fiscal federalism was more like that of the US. But when Premier Zhu

\footnotetext{
${ }^{10}$ For a meticulous documentation of the evolution of China's residential registration system, see Cheng (1991). An updated version of this thesis, which covers recent changes of the system, is available from Cheng. According to him, urban residents have more voting rights than rural residents in China.
} 
moves to increase the power of the central government in the post-Deng era, the fiscal system becomes far away from the fiscal federalism in the US.

China still had a great scope for the strategy of big push industrialization and imitation when it entered the reform era. The high income share of the traditional autarchic sector in China implies that it still has room to mimic the efficient pattern of division of labor in the capitalist developed economy in the absence of private property rights and market. But the potential benefit for this strategy had been already exhausted in the Soviet Union when it started its reform program.

But China's impressive development performance is not only due to the potential for mimicking the old capitalist industrialization pattern. Also, a great variety of social experiments in Japan, Hong Kong, Taiwan, South Korea, and other East Asian countries provides room for a new mimicking strategy. The newly industrialized capitalist economies provided free information on a new pattern of industrialization of laborintensive exports. This pattern exploits a significant differential in per capita real income between developed and less developed economies to export labor-intensive manufactured goods in exchange for capital-intensive equipment. Ethnic Chinese businessmen from Taiwan and Hong Kong bring human capital, entrepreneurial expertise, institutional knowledge, and capital, which are essential for the imitation of the new capitalist industrialization pattern, to China. The Chinese government also purposely learned from Taiwan and Hong Kong's experience. For instance, the special economic zone is certainly a direct imitation of the export process zone and the free trade zone in Taiwan and other capitalist countries. The zones significantly reduce transaction costs caused by tariff and other barriers to trade. Private rights of foreign direct investors are much better protected in the zones than in the rest of the host country. According to the theory of capital and division of labor in Yang (1999, see also Sachs and Yang, 2000, chapter 16) and the theory of indirect pricing in Yang and $\mathrm{Ng}$ (1995, see also Sachs and Yang, 2000, chapter 8), this implies that foreign entrepreneurs have a strong incentive to indirectly sell their entrepreneurial know-how to the host country via the institution of the firm.

But Deng's reform era shares two fundamental elements of Stalin and Mao's socialism: the party's monopoly of political power and the dominance of state owned firms. According to Lardy's documentation (1998), the state sector expands in terms of level of output and employment, employment share, and level and share of financial resources that it receives during the reform era. In the largest special zone, Shengzhen, state-owned firms dominate the economy. In 1992 when many government institutions were short of revenue, they were encouraged to found lucrative businesses to subsidy their expenses. Many new government enterprises and businesses were founded at very high speedy, so that $60-90 \%$ of government institutions run commercial businesses (Wen, 1999, pp. 319-27). The government institutions use their dual positions as regulation makers and enforcers and players in economic arena to pursue state opportunism. For instance a local government tax bureau runs a restaurant and uses predation tax to force other local restaurants to close and a police unit runs an enterprise producing firework and uses its power in issuing licenses to maintain its monopoly in this business (Wen, 1999, p. 321). The institutional characteristics imply institutionalized state opportunism and corruption. Economic development is still a hostage of the vested interests of the privileged class.

The most important characteristic of China's market-oriented reforms is the absence of constitutional order and the rule of law. This implies institutionalized state opportunism, self-dealing of the ruling class, and rampant corruption. We will analyze 
the features of the market-oriented reforms in the absence of constitutional order in section 5 .

In summary, China's impressive growth performance in the 1980s and 1990s can be attributed mainly to its low initial level of development (i.e., the nature of its recovery from disastrous Maoism) and to the new opportunity for mimicking the new exportoriented industrialization pattern. Deng's socialist market economy emerges and evolves from a mix of Mao's administrative decentralization and state-owned firms, and the imitation of Taiwan and Hong Kong's new development pattern. In this sense, Deng's socialist market system is different from Lange's market socialism, from Stalin's socialism that mimics the old capitalist industrialization pattern under central planning and the uniform state ownership of firms, and from Mao's socialism that does not copy any capitalist experience. It is possible that after the potential for mimicking has been exhausted, China's new pattern of socialism may fail to work, as what happened to Soviet style socialism after the successful imitation of old capitalist industrialization in the 1930s and 1950s.

Misunderstanding the initial conditions and driving forces of China and Russia's reforms generates many misleading views on the comparison between China and Russia's reforms.

The first of them is the overstatement of development performance of China by some China experts. As pointed out by Sachs and Woo (1999), China's broad growth performance is not better than the performance of other East Asian economies. Virtually every market economy in East Asia has grown very rapidly in the past thirty years, based on a strategy of rapid export growth of labor-intensive manufactures. During 1986-94, China averaged an annual per capita growth of around 5.6 to 6.8 percent in PPP-adjusted GDP. Other East Asian countries also showed equivalent or even higher rates of annual per capita growth in PPP-adjusted GDP over the longer period of 1965-90, including: Hong Kong, 5.8; Korea, 7.4; Singapore, 7.4; Taiwan, 6.3; Indonesia, 4.7; Malaysia, 4.5; and Thailand, 4.6. In addition, the difference in per capita real income between China and newly industrialized countries, such as Taiwan, is still increasing.

China's official statistics overstate real growth rates too. Lardy (1998) shows that official data overstate the growth rate by at least 1-2 \%. According to some Chinese scholars, such as Luo Shao (Economic Highlights, May 15, 1999, p. 1), the official data overstate growth rates by 2-3\%. Also, Lardy (1998) provides evidence that the Chinese government purposely hides information about bad loans of state banks and the financial state of state firms. China's development performance is greatly inferior to what the official data indicate. Wolf (1998, p. 17) shows that even if China's growth rates are much higher than Japan, Taiwan, South Korea, the US, and Germany, the difference in per capita real income between China and these countries will still increase before 2015 because of a very low absolute level of per capita real income in 1979 China. Hence, we must pay more attention to the absolute difference in per capita income level and its change than to the difference in growth rates.

Some economists argue that China's short-run impressive growth performance indicates that privatization of state-owned firms is not necessary for a successful transition. This is equivalent to the false statement that the Soviet Union's short-run impressive growth performance in the 1930s would ensure the long-run success of the Soviet socialist system. Other economists (Qian, 1999) consider China's fiscal federalism as the major explanation for impressive growth performance. This may not be very convincing, since post-communist Eastern Europe as a whole is much closer to a fiscal federalism than is China's communist centralized government system. The variety of 
institutional experiments in Eastern Europe is certainly much greater than in different provinces in China. If fiscal federalism is the most important determinant of the difference in transition performance, then it is Eastern Europe, rather than China, that should have better transition performance. As we discussed before, different initial conditions, different development stages, room for imitation, and inaccurate Chinese official data explain the differences in transition performance.

Economic transition is part of the transition in constitutional rules. Speed and the time path of the transition are determined by its driving mechanism. Hence, the next section will focus on the driving mechanisms for constitutional transition.

\section{Driving Mechanisms for Transition}

Many historians agree with the view that a great driving force for experiments with various institutions and diffusion and imitation of and transition to successful institutions in Western Europe is a geopolitical structure where no single overarching political power exists (Sachs and Yang, 2000, chapter 1). This implies that the sizes of major countries are close, so that there is no very large country that can dominate others in Western Europe. Intensive competition between many governments in small countries is conducive for the emergence of more capable governments. This can explain why large inland countries, such as Russia and China, are slower than other countries to adopt competitive institutions. This also explains why small island countries, such as Britain, Japan, and Taiwan, are more able to quickly adopt competitive institutions.

The renaissance in Western Europe had profound and complex effects in consolidating the decentralized political structure in Western Europe. On the ideological level, mankind and the meaning of life itself were put at the center of renewed philosophic speculation. On the economic level, the rise of competing city states in Renaissance Italy spurred the role of international trade, with the attendant market institutions of banking, contract law, shipping law, and secured transactions. Political speculations, crowned by Machiavelli's The Prince, explored ways for the Prince to strengthen the state in competition with other states, including the role of the state in fostering economic prosperity.

Throughout European history, innovations in economic and political life have started in one region and then spread to others on the basis of their perceived or demonstrated advantages, or through conquest, colonization, or imperial rule. It was considerably more difficult for new European ideas and institutions to spread into Russia and China's vast continental expanse. Institutional innovations carry less well into continental, largely self-contained societies, such as China, India, and Russia than they do into small, open societies that are dependent for their very survival on international trade, international alliances, and the timely adoption of "best practices" from abroad. Perhaps "small is beautiful" in economic reform, if the small entity isn't simply gobbled up by a larger power. ${ }^{-1}$ In any event, it is probably no accident that Russia, China, and India have had the most difficult time of all the traditional societies in the world in adopting the new political and economic institutions from

\footnotetext{
${ }^{11}$ Pipe (1999, p. 153) attributes the rise of parliamentarism in Britain and its decline in Spain and France in the middle age to the small size of Britain relative to that in Spain and France.
} 
abroad, even when those institutions have an overwhelming track record of effectiveness.

Sachs and Woo (1999) and Roland (2000) have provided evidence that small transition economies have greater state capacity in managing transition. They gain institutional knowledge faster and can manage rapid transition better than large size of transition countries (Sachs and Woo, 1999, p. 14). A quite successful Eastern European-style "big bang" in Vietnam in 1989 might be partly attributed to the small size of this country.

The post-socialist countries in Eastern Europe and the current transitional economies in Asia provide a sufficiently great genetic diversity of countries and cultures for a great variety of institutional experiments with transition from the socialist system to the capitalist one, with which human society has no previous experience. Simultaneous experiments with various patterns and speeds of transition in many countries may provide the opportunity to quickly acquire institutional knowledge about transition.

Many economists may argue that particular historical and cultural traditions of different developing countries may lead to different institutional transition paths. Asking all countries to follow the same transitional path might be criticized as an outdated imperialist attitude and a self-centered view of the western cultural tradition. The development experience in many countries seems to reject this criticism. Some countries, such as the Soviet Union and 1949-1979 China, tried to mimic capitalist industrialization without the capitalist legal system and property right structure and failed. Other countries, such as Taiwan and South Korea, tried to mimic the capitalist legal system and property right structure without a democratic political system before the end of the 1980s. They realized that this does not work and finally initiated the transition to a constitutional democracy at the end of the 1980s. Japan mimicked all the capitalist legal, political, and economic institutions from Britain and Germany, but kept the Emperor's substantive power. It had very successful economic development in the absence of real constitutional checks and balances of the Emperor's power. Then it entered WWII, aggressing upon China and other countries and bringing disaster to the Japanese, Chinese, and other Asian peoples. Even after the big-bang constitutional transition under the American military occupation, Japan still kept some of the "Asian behavior norms" for the relationship between the government and private business, which caused the troubles in 1990 financial crisis.

All this experience suggests that there is a universal institutional core that is essential for long-term successful economic development. Hence, the transition is a harmonization process of the institutions in ex-socialist countries with global capitalist institutions, rather than a process to create institutional innovations that are substantially different from the capitalist institutions (Sachs and Woo, 1999).

\section{Market-oriented Reforms Associated with the Transition of Constitutional Rules}

There are two patterns of transition. One is adopted by Eastern Europe and Russia, in which market-oriented reforms are just a small part of the transition of constitutional rules. The other is adopted by China and Vietnam, in which market-oriented reforms are implemented under communist game rules (i.e., a communist monopoly of political power). We consider first in this section the former pattern of transition. 


\section{Example 1: Russia's constitutional transition}

As Sachs and Pistor (1997, pp 3-5) indicate, the tradition to the rule of law in Russia has been absent. In the first stage of the transition from January 1992 to October 1993, reforms were implemented under the old communist regime. During this period, economic reforms were launched consisting of three major pillars: price and trade liberalization, stabilization, and privatization. From the very beginning, all of these measures remained incomplete, and indeed some of them failed during this period. The record of stunted reforms is linked to the absence of constitutional order in several ways. First, the government often lacked the political and constitutional means to implement reforms, especially in the face of entrenched opposition from the communist-era Supreme Soviet. Equally important, the government lacked constitutional restraints on its own behavior, so that many opportunities for reform were squandered by official abuse and corruption.

The failure of stabilization, for example, can be traced proximately to the behavior of the Russian Central Bank, which issued massive and inflationary credits to the economy. The explosion of credits mainly followed the appointment of $\mathrm{Mr}$. Viktor Gerashchenko, the Communist-era head of Soviet Gosbank, as chairman of the Central Bank in June 1992. During 1992 and 1993, the Russian Central Bank transferred a very large proportion of national income (perhaps as much as $40 \%$ of GDP in 1992, and 20\% of GDP in 1993) to key pressure groups, political favorites of the Government and the Bank, and various cronies of leading officials, with the transfers being financed by the inflation tax imposed on the society at large. The Bank's books were unauditable, with large flows of untraceable money.

The common denominator of all these distortions to the reform process was the absence of rule of law in government decision making and executive authority. Procedures were ad hoc, non-transparent, and often corrupt. Civil society was too weak to offer important countervailing pressures, so that abuses went largely unchecked. Decision making was not guided by general legal norms evenly applied, but was rather individualized to particular enterprises and pressure groups.

The first phase of reforms saw the eruption of political power struggles that brought the country to the edge of a civil war. The second phase, which started in October 1993 and went until the present saw the consolidation of political and economic power by those who had gained the most during the first phase. This consolidation was accompanied by governance of more orderly rules, if not always by formal law. The state Duma operated under the new rules, and elections were held as scheduled in December 1995. In addition, presidential elections were held on schedule at the end of Yeltsin's five-year term. At the same time, many deep constitutional problems remained. Struggles over executive power continued in a new though less dramatic guise, between the government and various parts of the presidential apparatus. After 1992, the presidential apparatus grew to enormous proportions outside constitutional constraints or public oversight.

Whether the rule of law has taken hold in Russia is a difficult question to answer. Countries that respect the rule of law usually share the following features: they "divide the powers of government among separate branches; entrench civil liberties (notably, due process of law and equal protection of law) behind constitutional walls; and provide for the orderly transfer of political power through fair elections" (Sachs and Pistor, 1997). The subjection of the sovereign to predetermined legal constraints affects public and private law development in a given country. Where this is the case, 
arbitrary state interference is minimized, and state action - as a regulator, tax administrator, or contract enforcer - becomes impartial and predictable.

It takes time to reform the judicial system, to train and/or to replace its personnel, and to replace existing laws with new ones. Nevertheless, it is important to assess whether the commitment to the rule of law, as opposed to personal fiat, however well intentioned, is apparent. Indicators for such a commitment include the division of powers, civil liberties, independent judiciary, and the orderly transfer of power.

Before 1991, hardly any of these features were established in Russia. As of 1996, a number of important achievements have come about. A new Constitution is in place which, despite some doubts about the validity of the procedure by which it was adopted, has apparently found widespread legitimacy. Two parliamentary elections have been held under this Constitution. Most importantly, perhaps, presidential elections have been held and the unsuccessful contender accepted them.

These achievements are significant, indeed remarkable, but we should also note that Russia has not yet experienced an orderly transfer of political power, so that the hardest test of the new constitutional order has not yet been seen.

The new constitution acknowledges the separation of powers, but a closer examination reveals the limits of these nominal commitments. In particular, the division of power between the legislature and the executive is blurred. This is most visible in the legislative powers allocated to the President. The President may rule by decree, and his decrees are binding as law.

It is worth noting that most provisions of the Constitution would not hold water if legally contested. The liberal idea that civil rights are natural-law rights and shall be used as a defense against the state seems alien to the Russian Constitution. In its language, the state grants these rights to its subjects. But what the state grants, it may also take away again. In addition, the Constitution lacks the crucial procedural safeguards to ensure the effectuation of civil liberties, including equal protection of the law. "Special" laws designed for a particular person or entity, as opposed to general laws addressed to an anonymous or only generally defined target group, have been rampant in Russia. They provide the legal basis for tax exemptions, special privatization rules, and allocation of rights to those with the best access to the President's decree power. As a result, the state retains ample scope for arbitrariness, which not only creates uncertainty, but also provides a breeding ground for corruption.

Gray and Hendley (1997) set out three basic conditions for law-based private transacting, which are good laws, sound supportive institutions, and market based incentives that create a demand for law and legal institutions. Drawing from a comparison with commercial law development in Hungary, they suggest that the development of effective judicial and administrative support institutions is the most difficult task to accomplish, not only in Russia, but also in other transition economies. However, Russia still falls short of providing the first conditions for law-based transactions: good laws that reduce transaction costs and enable private actors to mobilize their own rights. Pistor (1997) discusses the implications of the lack of a comprehensive corporate law at the outset of privatization for the development of property rights and corporate governance post-privatization. She traces the nature and quality of legal rules issued in post-socialist Russia, not only to Russia's legal tradition, but also to policy choices made by reformers during the course of economic reform. She argues that comprehensive legal reform was delayed in favor of speedy economic reforms based on ad hoc decision making and decrees with detrimental consequences for the development of property rights and governance structures. 
As indicated by Sachs and Pistor (1997), the roots of Russian exceptionalism in the rule of law and in the lack of economic freedom, in comparison with the rest of Europe, - are deep. The exceptionalism far predates the 1917 Bolshevik Revolution, and indeed was already dramatic in the mid- $19^{\text {th }}$ century, when Alexander II launched his attempts at the Great Reforms (described by Owen, 1997). The exceptionalism can be traced back several centuries, plausibly to the start of the Muscovite state.

Following the emergence of Moscovy from more than two centuries of Mongol domination (1240-1480), law has played a conspicuously less important role than in Western Europe. The great formative stages of Western European law - the application of Roman Law by medieval Europe; the struggle of the Princes and the Papacy over political authority and legitimacy; the Renaissance and the Enlightenment - touched Russia only indirectly. Perhaps equally important, after the $16^{\text {th }}$ century, the Russian Orthodox Church was subsumed in state power. The Tsar was both the head of state and the head of the Russian Orthodox Church. This dual role eliminated one of Western Europe's key bulwarks against the concentration of power in the hands of a single ruler. Medieval Europe's prolonged struggle between Church and State over sovereign authority, natural law, and political legitimacy played a fundamental role in fostering law-bound state power and bolstering standards of political morality; in Russia, by contrast, the struggle ended in a dominant state and a politically subservient Church.

The trade off between the benefit of constitutionalism and the demand for flexible and great executive power (Hellman, 1997), which was the focus of the debate among Russian economists and policy makers, is similar to the trade off between the reduction of resistance from the vested interests and institutionalization of state opportunism of the dual track approach in China. Shleifer $(1994,1998)$ has made an argument in support of Russia's shock therapy. According to him, corruption, which is associated with evolutionary approach to reforms, is a way to buy out the monopoly power of the privileged class. However, he goes on, corruption is not an effective method of reform for two reasons. First, the implicit contracts based on corruption are not easy to enforce because the entitlement for selling government officials' control rights is not legally well defined. Second, tolerance of corruption will generate incentives for creating more government officials' control rights. Hence, the most efficient way to initiate reforms is to remove government officials' control rights through the kind of privatization reform seen in Eastern Europe and Russia. But as Sachs and Pistor (1997) suggest, the success of liberalization and privatization reforms is dependent on the transition to constitutional order.

Hellman (1997, p. 58) provides empirical evidence for a positive correlation between growth performance and the passage of constitutions in East and Central Europe. The result is not convincing, since the transition of constitutional rules is a very complicated and long process. Compared to short-term negative effects of the transition of constitutional rules in the American Independence War and Civil War on economic growth, the current difficulties in Russia's transition are not unusual and cannot be attributed to the shock therapy approach. But because of the lack of any tradition of rule of the law in Russia, Russia's transition might be more difficult than were American and French transitions in the $17^{\text {th }}$ and $19^{\text {th }}$ century. It took one century for France to transition from the Old Regime to the new constitutional order. Russia is a large and mainly inland country, with a history that is more unfavorable to the transition. It is likely that Russia's transition from communism to the new constitutional order is as difficult as was France's transition in the $19^{\text {th }}$ century. 
Many scholars attribute Russia's poor transition performance to weak enforcement of laws. However, as Pistor (1997) points out, the weak enforcement is due to bad laws and state opportunism. A comparison between 18 century Britain and France by North $(1981,147,158-170)$ also suggests that a great state taxation and law enforcement capacity in Britain was due to fair constitutional order and weak state capacity for taxation and law enforcement in France's old regime was due to state opportunism and to the absence of fair constitutional rules. Chinese case provides another support for this view. Since the Chinese communist party's monopoly of political power institutionalizes state opportunism that uses laws (which are often bad laws) to pursue interests of party apparatus at the expenses of society at large. This "rule by laws," distinguished from the rule of law, makes the law enforcement in China very weak. Many court rulings cannot be enforced in the 1990s (He, 1997).

\section{Market-oriented Reforms in the Absence of Constitutional Order}

China's dual track approach is representative of the market-oriented reforms in the absence of constitutional order. China's Constitution (http://www.quis.net/chinalaw) is similar to other socialist constitutions in giving the Communist Party a monopoly of political power and in rejecting the notions of division and of checks and balances of power. One of the differences between China's Constitution and that of the Soviet Union is that in its preamble, the ideology of Marxism, Leninism, and Mao thoughts are taken as the source of the legitimacy of the power structure in China. Although Western scholars of law consider the preamble as having no legal implication, its notion on the source of power is similar to the old notion of the origin of power being Divine, rather than from contract and the consensus of the ruled. Western negative constitutionalists, such as Pilon (1998), would pay particular attention to the three features of the Chinese Constitution. First, it is programmatic. It sets up a specific agenda for building socialism. Hence, it is more like the bylaws of China, Incorporated. Second, in the Chinese Constitution, there are no genuine provisions for popular ratification. It gives no indication how citizens join or consent to so farreaching a program. It thus raises fundamental questions about the legitimacy of Chinese Constitution. Finally, all citizens' rights are given by the state and party apparatus, but monopoly of power by the state and party apparatus is given from "Divine" - ideology of Marxism, Leninism, and Mao Thoughts, which needs no justification. Hence, Pilon (1998, p. 355) calls the Chinese Constitution "a program for unlimited government."12

So far, no influential movement to reject the Constitution has been developed in China. The sense of crisis among Chinese people is not strong enough. This, together with the large size of China, implies that pressure for the transition of constitutional rules is too small for serious consideration of such a transition. Hence, China's market-oriented reforms can be conducted only within a "bird cage" of communist game rules. It is not surprising that reforms are hijacked by the vested interests of the party apparatus.

The arrangements in which the rule maker, the referee, the rule enforcer, and the player are all the same party apparatus institutionalize state opportunism, which

\footnotetext{
${ }^{12}$ For history of the Constitution of People's Republic of China and its recent amendments, see Pilon (1998), Yang (1994), and Qian (1999).
} 
pursues the party's interests even if social welfare is sacrificed. The state opportunism is illustrated by the government's control of the entry of private firms into the important sectors and state predation of private firms. There is a list of sectors in which domestic private firms are not allowed to operate. The sectors include the banking sector, post and telecommunications, railroads, airlines, insurance, the space industry, petroleum chemistry, steel and iron, publications, wholesale business, news, and others. In addition to the thirty sectors, private firms are restricted from operating in another dozen sectors, including automobile manufacturing, electronic appliances, and travel agencies (Huang, 1993, p. 88). In addition, a stiff licensing system for international trade, wholesale and retail distribution networks, publication, and many other businesses eliminates many lucrative opportunities for private business, generating trade conflict with the US and other developed countries. In particular, all government institutions which have power to issue licenses have vested interests in the sector where licensees operate. For instance, the license for international trade is issued by the Trade Ministry, which is the largest owner of trade companies in China. The license for the wholesale and retail distribution network is issued by the local government committee which owns local state distribution networks. Of course, the principle for issuing a license is to promote the monopoly interest of the government institutions.

Mueller (1998) documents the adverse effects of state monopoly of the telecommunications sector on economic development. This monopoly implies that the regulation maker of this sector, the major player, and the referee who enforces the regulation are the same state organization. State opportunism is then institutionalized and retards economic development. Also, China has a very stiff government approval system of founding firms. There is neither free association nor automatic registration of a company except in the Hainan Province (Mao, 1999, Pei, 1998). Also, there are arbitrary and often very high registration capital requirements for founding firms. This, together with the residential registration system and the state monopoly in the housing and banking sectors, provides many effective control methods that can be used to pursue state opportunism. As Pilon (1998) points out, all the self-dealing is, of course, supported by the fundamental game rules in China's Constitution.

State predation of private firms started in political campaigns in the early 1950s. According to Bai, et al, (1999), it has continued in the reform era. One persistent cause is the ideological discrimination against private businesses amid power struggles and ideological debates within the government. As Bai, et al (1999) document, another form of state predation in the reform era was simply revenue grabbing. Governments of different levels tended to impose various kinds of taxes and fees in order to grab as much of the observable revenue from their business jurisdiction as possible. A 1988 study of private firms in Liaoning Province found that taxes and subcharges alone would take away $63 \%$ of the observed enterprise profits. When the scores of different fees were also taken into account, the tax burden was even higher. Such a tax burden made it hard for private firms to survive, unless they evaded taxes and fees by hiding their transactions and revenue (China Economic Almanac, 1989, p. 107). Ten years later, a 1998 study of private firms in the Anhui Province reported that gross profits for many products was about $10 \%$ of total revenue, whereas total taxes and fees added up to more than $10 \%$. There were more than 50 types of fees imposed on a private business, and some types of these fees are prohibited by the government's own publicized regulations and rules. This study reached the conclusion that "owners who do not want to close down their businesses had no choice but to evade taxes" by hiding revenue (Jilin Daily, May 30, 1998). 
Peasants in the rural areas were major victims of excessive taxes and fees. Throughout the reform period, the government made countless promises to reduce extortive levies and the discretionary tax on peasants, but extortive levies and discretionary taxation continued to be widespread. In some places, 61 different types of fees were charged (Ding, Yan, and Yang eds., 1995).

China started to mimic western style laws in the 1990s. But under the communist constitutional rules, the laws, such as the Corporation Law passed in 1994, and the Anti-Unfair Competition Law passed in 1993, cannot be implemented. The incompatibility between Corporation Law and the communist constitutional rules is noted by Yang (1998) and that between the state monopoly in the telecommunications sector and Anti-unfair Competition Law is noted by Mueller (1998, p. 200). It might be concluded that imitation of many Western style laws would not work within the communist constitutional rules. The constitutional constraint implies that China's reforms can only follow the dual track approach. This approach generates long-term costs that likely outweigh its short-term benefit of buying out the vested interests of the privileged class. We will use several examples to illustrate this point. $\frac{13}{13}$

\section{Example 2: China's rural reform and land system}

The first example is China's rural reforms and land system (see Yang, Wang, Wills, 1992, Sachs and Woo, 1999, p. 30, and Wu, 1998). In China's rural reforms, use rights of land that is collectively owned by villagers were given to farmers in the end of the 1970s. The sale of land was strictly prohibited in the 1980s, though transfer of use rights has been permitted under tight regulations since 1984 (Yang, Wang, Wills, 1992 , p. 18). Village cadres control reallocation of land according to changes in village population. The data suggest that the impressive agricultural growth in the early years of agriculture reform was a one-shot improvement in productivity that followed the liberalization of the agricultural sector and the introduction of the household responsibility system for land tenure. A simple extrapolation exercise indicates that the big achievement of the 1978 agriculture was to return rice and wheat yields to their underlying trends that were suppressed by the stringent collectivist agriculture practices of the 1958-1977 era.. 14

Growth of the agricultural sector slows down after 1985 due to three factors. The first factor was farmers' uncertainty about future land use rights. Despite the 1984 government decision that farmers could get leases up to fifteen years long, Prosterman, Hanstad and $\mathrm{Li}$ (1996) found in their field work the following fact. "Local officials have not implemented this policy to any significant degree... [In] many villages, representatives from the collective take back all the land in the village every three to six years and reallocate the plots to adjust for changes in household size. The result is that farmers have refrained from making the many small long-term improvements (e.g. digging wells and small feeder drains applying more organic fertilizer) in the land that would have increased grain yield.'

Johnson (1994) pointed out that some of the government's policy responses to the post-1985 slowdown increased farmers' concerns about land security, and hence

\footnotetext{
${ }^{13}$ See Roland (2000, p. 15, p. 198) for the cost of dual track approach.

14 Specifically, the 1982-91 yield levels for rice and wheat lie on the straight lines extrapolated from the 1952 yield levels using the yield growth rates of the 1952-57 period.

15 To us, this finding of widespread uncertainty about future land use rights explains the long time puzzle why rural land markets in China have been surprisingly inactive despite the legality of lease transfers. For another case-study, see "No Rights Mean No Incentive for China's Farmers," New York Times, December 15, 1996.
} 
reduced farmers' work efforts and investments in the land. For example, the government announced in late 1990 that some farming operations, like plowing, fertilizing and harvesting, would be re-collectivized in order to reap economies of scale from mechanization.

The second important factor for agriculture stagnation is that the state monopoly of the procurement and distribution network of grain has been strengthened since 1994 (Lin, 1998, p. 68). The monopolized distribution system causes an appallingly large scale of corruption and waste. When the state decided to clamp down on inflation in late 1993, grain procurement quotas were re-introduced and price controls were put on 27 agricultural commodities. Worse yet, whenever credit was tightened to fight inflation (1985, 1989 and 1992), the government would pay for part of its grain procurement with coupons (IOUs) instead of cash (Sachs and Woo, 1999). This also explains the flagging growth in grain production.

A third factor contributing to the post-1985 slowdown in agricultural productivity growth has been the large reductions in investment in agricultural infrastructure (e.g. irrigation works) in the years after 1979. The level of real investment in agricultural infrastructure in 1994, for example, was only 58 percent of the 1979 level. It appears, however, that in many rural areas the decline of state investment in agricultural infrastructure was accompanied by a reduction in state efforts to develop human resources. This can be explained by the absence of a land market and related contracts. Even in the absence of state investment, the agricultural infrastructure can be developed by land related contracts. But within the institutional constraint, project contracts based on land entitlement are not feasible. Also, in the absence of land trade, local governments cannot raise revenue on property tax and sales tax of land. The local government must use profit of township and village enterprises, expropriate tax, and discretional fees to raise enough revenue to keep the spirit of local officers and to infrastructure construction. But this institutionalizes corruption and other opportunism by local officers, thereby restricting government fund raising capacity.

According to Wu's documentation (1998), this dual track approach to land ownership generates a dilemma between the efficient commercial use of land and social justice. Many local officers in coastal provinces divide village owned land into two parts: land that can be leased to foreign or private companies for commercial use and land used by villagers for household farming. Under the "dual land system," village officers gain control rights to commercial land and grab rents from it. In exchanges, villagers claim priority rights to employment in the firms leasing land. But the difference between the rents and employment income is huge. Hence, the whole process is that the local officers steal rents from villagers who collectively own land. Since this stealing is so unjust, many farmer protests have taken place. The central government was forced to prohibit the practice of the dual land system. This prohibition retards local industrialization and eliminates many socially beneficial business opportunities.

In summary, the institutional constraint imposed by the communist Constitution generates dilemma between justice and efficiency. The dual track approach developed under market-oriented reforms in the absence of constitutional order institutionalizes corruption and opportunistic behavior by government officers and creates more obstacles to constitutional transition. Yang, Wang, and Wills (1992) estimate the degree of transferability of rural land in China and estimate the potential gains of privatization of land ownership. According to their econometric model of the relationship among per capita real income, the degree of commercialization (level of division of labor), and efficiency indices of specifying and enforcing property rights, 
Chinese peasants' per capita real income would increase by $30 \%$ if free land trade were allowed in 1987. This again verifies Sachs and Woo's claim that despite (rather than "because of") the dual track approach, China's agricultural sector has had quite an impressive development performance. But if the dual track approach were replaced by a transition to complete private ownership of land as in pre-1949 China, China's economic performance would be even better and the current agricultural stagnation would not occur.

\section{Example 3: China's township-village-enterprise}

The second example of the dual track approach is Chinas' township-village-enterprise (TVE). As Sachs and Woo (1999) indicate, there are two common usages of the term TVE that can be potentially confusing: the official usage in statistical collection and the academic usage in discussion of ownership-type. The official statistical meaning has broadened over time. Prior to 1984, TVE referred to township-owned or villageowned, and from 1984 onward, TVE statistics also include joint-owned (by several persons or families) and individual-owned (by one person or family hiring less than seven employees). The present official statistical usage gives the impression of TVEs being overwhelmingly private in nature, because 87 percent of TVEs in 1994 were individual-owned. Individual-owned TVE produced less than 27 percent of TVE output, and less than 19 percent of industrial TVE output. 16

However, most academic discussions on the ownership structure of TVEs implicitly use a narrower definition that covers only the enterprises that are registered formally (and increasingly falsely, in our opinion) as township-owned and villageowned. This implicitly narrow definition explains why Naughton (1994a) and Walder (1995a) categorically described TVEs as "local government-owned." Unless otherwise noted, we will adhere to this narrow definition of TVEs as public-owned in the following analysis on the "ownership nature of TVEs."

The TVE is hardly innovative, since such local government or collectively owned firms were experimented with in many countries, such as Japan and Qing Dynasty China, in the end of the $19^{\text {th }}$ century. But under a constitutional order that protects private rights of firms, such firms and collectively owned firms are not competitive in most cases. The TVEs operate entirely outside of the state plan, and with rather hard budget constraints (receiving few subsidies from the state budget of the central and provincial governments, and only rarely from local government).

Without question, local governments have viewed the TVEs as an important potential source of revenues for local budgets (Oi 1992). In the early 1980s, the central government introduced the explicit tax contract, a system of fiscal contracts where the central government negotiated a revenue quota with each province. This fiscal contract arrangement is replicated at each level of government down to the township level. This revision in fiscal relations makes the local governments the residual claimants of income generated by any firms established by them at the local level. "As a result, local governments use every method possible, including many which straddle the boundaries of legality, to promote rural industry, at the same time milking it to supplement their government budgets" (Zweig, 1991).

\footnotetext{
${ }^{16}$ Data are from the 1992 TVE Yearbook. Li (1999) documents a case of spontaneous privatization of TVE via the transformation to public holding companies in Shunde county of Guangdong province. According to him, a long spontaneous privatization process since the end of the 1980s has already transformed most TVEs in this county to joint stock companies. In the end of the 1990s, private firms become dominant players in this county though corruption, predation, and other state opportunism are rampant.
} 
Some economists view TVEs as an important and highly successful institutional innovation, melding market incentives with public ownership. Others, by contrast, view them as a partially successful half-way house on the way to real private ownership. While the former emphasize the special fit of the TVEs with China's undeveloped economic conditions, the latter emphasize the serious institutional constraint and problems ahead unless China moves now to real privatization of the TVEs (Sachs and Woo, 1999).

The foundation for collective-owned rural industrial enterprises was laid during the decade-long Cultural Revolution, when the official emphasis on self-reliance and the breakdown of the national distribution system caused the rural communes to expand their non-agricultural activities. These commune-brigade enterprises were relabeled as TVEs when the commune system began to dissolve in 1979. The concern for rural underemployment and local development has led to steady liberalization of the rules governing the formation of TVEs; and since 1984, the terms of approval and supervision of TVEs have varied greatly across regions.

Given the varieties of TVEs, the vagueness about their ownership and control, and their evolving nature, it is therefore natural that different authors have emphasized different "basic" characteristics of the TVEs, often without acknowledging their great diversity over time and space. For example, Nee (1996) regards TVEs as informal joint ventures between the state and the private sector, often with "extensive informal privatization of collective-owned assets and firms," whereas Walder (1995a) views TVEs as "under a form of public ownership no different from the large urban state sector." Peng (1992) emphasizes the "semi-private" nature of TVEs to explain their operational autonomy, while Oi (1995) accents a state-centered view in which TVEs are the production units in "a large multi-level corporation" managed by the countytownship-village hierarchy. 17 The terminological haze has thickened in the 1990s with the additional easing of restrictions on the registration of firms as TVEs, making the co-existence of true TVEs and red-capped private enterprises a common phenomenon in many places, as stressed by Ronnas (1993).

The TVE system in the reform era inherits many advantages as well as disadvantages of Mao's commune and brigade firms. It distorts the geographical location of firms, retards efficient urbanization, relocates resources from large state firms with advanced technology to local firms with inferior technology, and creates a Chinese style dualism: the coexistence of flexible TVEs with inferior technology and rigid, large state firms with superior technology. 18 This dualism implies a dilemma between the exploitation of technology and location efficiency and the exploitation of X efficiency. Hence, impressive growth of the TVEs has its cost too. Under a free enterprise system, many TVEs might be replaced by large private firms located in the urban areas, which are more competitive than large state firms in urban areas. Hence, from this view, a very high growth rate of TVEs might be inefficient. Alwyn Young (1999) provides empirical evidence for the distortions generated by TVEs and related regional decentralization.

TVE shares all the common flaws of the enterprise system under local government control. It generates unfair game rules since the rule maker, the referee, and the player are the same local government. It institutionalizes state opportunism and corruption. Hence, game rules are not stable, transparent, and credible. The adverse effects of the TVE on economic development have not received enough attention, while many China

\footnotetext{
17 According to Oi, the county government was corporate headquarters, the township governments were regional headquarters, and the villages were companies.

${ }^{18}$ China's degree of urbanization is much lower than in capitalist economies with similar per capita real income (He, 1997, p. 275).
} 
specialists have paid a great deal of attention to its advantage compared to the Soviet style system of state firms under the complete control of the central government. The TVEs have a harder budget constraint than do state firms owned by higher levels of government. They as a whole are more competitive than state owned firms. According to Wu's excellent field work (1998), the TVE, together with the half-way house approach to reforms of the land ownership system and with the residential registration system, generates a very peculiar Chinese style feudal system. In this system, local government officers' territory jurisdiction power, judiciary and enforcement power, control rights to land, official position in the party apparatus, rights to founding firms, rights to raising money, and control rights to the TVE are not separable, just like in a feudal system in Europe in the Middle Ages. The case of Daqiuzhuang illustrates the characteristics of the feudal system (He, 1997). Party head Yu Zuomin in village Daqiuzhuang blocked the state police's enforcement of the court order in a murder case. $\mathrm{Yu}$ is the leading government officer, party head as well as the president of all TVEs of this village. He controls the local paramilitary force and has de facto judicial power. Many media reports also indicate that local government officers use the TVE as a vehicle for predation. They force village folk to contribute to funds for setting up a TVE and to take on all the risk of the venture. Revenue from the venture is then grabbed by the officers (He, 1997).

Under the Chinese style feudal system, people are ranked as different groups with different rights. The local party officers are first-class citizens who have all rights and privilege to pursue their vested interests at the cost of others. The second class of citizens are village folks who have local residency. They can get good jobs in the TVEs and claim part of the welfare fund of the village. The third class of citizens are migrants who do the dirtiest job in the TVEs and cannot receive any part of the welfare benefits. This is similar to a feudal system, since an individual's social and economic position is determined by her political and residential stature rather than by her income and her constitutional rights. The Chinese style communist-feudal system, together with low labor mobility caused by the residential registration system and the state housing system in cities, explains why local government and collectively owned firms boom in rural China, while they are not as competitive as capitalist firms in the capitalist economies, where individuals have personal freedom and can freely trade labor, capital, land, and other properties. The feudal system and low labor mobility imply that community members expect to remain in the same place indefinitely and the common interests of residents in the same local community are quite stable. Hence, they have more incentive to contribute to the TVEs than they would in a free market system.

This new feudal system not only distorts the matching between managers and firms, the geographical location pattern of firms and resource allocation, and retards urbanization, it also generates social injustice that may cause social unrest.

The TVE ownership structure is highly unusual by international standards. In most East Asian countries with rural industry, such as Indonesia and Thailand, ownership of small enterprises is private, often within a family. By contrast, TVE ownership is collective, at least officially. Some scholars have argued that collective ownership reflects deep Chinese cultural patterns (Weitzman and Xu 1994). However, this "cooperative culture" hypothesis would appear to be called into question by the dominance of small private enterprises in rural Taiwan, as well as by the prevalence of small, Chinese-owned private firms throughout East Asia. If there is any cultural affinity regarding small business, it would seem to be for private, family-owned businesses rather than collectively owned businesses.

Other scholars have said that collective ownership is an effective way to raise capital funds for rural enterprise and to reduce the principal-agent problem by 
shortening the supervision distance (Oi, 1995, and Walder, 1995a). They use these reasons to interpret the TVE ownership structure as a good adaptation to market failures caused by China's underdeveloped markets for factors of production. According to Naughton (1994a), "Banks are ill-equipped in the early stages of transition to process small-scale lending applications and assess risks. Local government ownership in China played a crucial role in financial intermediation. Local governments could better assess the risks of start-up businesses under their control ... and serve as guarantors of loans to individual TVEs."

Some economists have even interpreted the TVE record as definitive proof against the conventional wisdom that private ownership is the natural ownership form of small-scale enterprises, and argued that what mattered for efficiency is not ownership but competition in product and factor markets (Nolan 1993).

Sachs and Woo (1999) are skeptical of this functionalistic explanation of TVE ownership form, especially of its emphasis on the state's superiority in financial intermediation. Taiwan's small and medium private enterprises exhibited dynamic growth in the 1960-1985 period even though they were heavily discriminated against by the wholly state-owned banking system. The informal financial markets (curb markets) appeared "spontaneously" to cater to their needs (Shea and Yang, 1994). The power of market forces (when tolerated by the local authorities) to induce financial institutional innovations was also recently seen in Wenzhou city in Zhejiang Province when economic liberalization began in 1979. Liu (1992) reported that "Ninety-five per cent of the total capital needed by the local private sector has been supplied by 'underground' private financial organizations, such as money clubs, specialized financial households and money shops ..."

An adequate general theory for TVE ownership structure should be based on two main considerations. First, private ownership was heavily regulated and discriminated against in many areas until recently. While individual ownership was given constitutional protection in 1978, private ownership, which is considered different from individual-ownership in China was given constitutional protection only in 1987. Therefore, (registered) collective ownership of rural industry arose as the primary response to the profitable niches created by central planning because of the severe disadvantages faced by enterprises registered as privately owned. Zhang (1993), using "non-collective TVEs" to refer to partnerships and individual and private enterprises, reported that "in virtually all aspects relating to local governments, the non-collective TVEs tend to be unfavorably treated .. (compared to) their collective counterparts. Areas in which local governments appear to have discriminated against non-collective TVEs include access to bank credits, to larger production premises, to government allocation of inputs and energy, to government assistance in solving technical problems and for initiating joint ventures and so forth. In the field of taxation and profit distribution, there is evidence that non-collective TVEs run a greater risk of being excessively levied, and that local governments tend to treat the non-collective TVEs more arbitrarily than they do the collective ones."

In short, the "market failures" identified by some China experts are not caused by inefficiencies intrinsic to a private market economy (like externalities and public goods). These so-called market failures are actually created by ideologicallymotivated constraints imposed by the state. Specifically, the banks have extended more loans to TVEs than to private enterprises because of state directives, and not

\footnotetext{
${ }^{19}$ Despite the great contributions of local private banks to economic development, the government still follows the regulation that prohibits private banking business and closes many local private banks (Lardy, 1998a, pp. 53-57).
} 
because of the TVEs being intrinsically more efficient or because of the local banks' recognition that the local governments were better assessors of risks than they themselves (Chang and Wang, 1994).

There is general assent that the TVEs face stronger market incentives (including harder budget constraints) than do the state owned enterprises (SOEs). As shown in Sachs and Woo (1999), two of the three types of TVEs, the Jiangsu and Zhejiang types are fairly similar in essence to the red-capped private enterprises. The local officials have the private incentive to maximize the profits of TVEs because "the careers and salaries of officials at the county, township and village levels are directly affected by the performance and growth of their rural enterprises" (Oi, 1995), and because neither local residents nor workers have access to legal, formal channels to exercise their ownership rights. In short, informal privatization by local officials has reduced the principal-agent problem and rendered the TVEs more efficient than the SOEs. 20 This private-incentive (informal privatization) hypothesis would explain why Peng (1992) found that the wage determination process was the same for rural public enterprises and rural private enterprises.

If this interpretation of "informal privatization" is valid, then continued TVE efficiency is possible only if the group cohesion of local officials does not degenerate into individual efforts at asset-stripping. We see the key to the group cohesion in Jiangsu and Shandong in the 1980s to be the heavy discrimination against private enterprises in these regions. The resulting lack of economic space in these regions to hide looted assets diminished the incentive for individual officials to rob the TVEs they oversaw. Without the strong legal discrimination against private property, assetstripping would have occurred more freely, and the inefficiency normally observed with informal privatization would have become more prevalent.

If this view is correct, the crucial implication is that gradual growth in the relative size of the private sector and in labor mobility will eventually undermine the group cohesion among local officials against individual asset-stripping (by providing secured hiding places for looted property), and thereby damage TVE performance.

With the further reduction in discrimination against private ownership since early 1992, intended to ameliorate the rural unemployment caused by the 1989-91 austerity policies, many TVEs have been taking off their "red hats" - albeit with difficulties in many cases.

As China heads toward a market economy, an increasing number of private companies are no longer feeling the need to register as "red cap" or collectivelyowned ventures because the difference in preferential treatment between private and public units has been narrowed. But there is a problem. The collective units are now arguing that private firms could not have developed without their help. As the socalled "owners" of the companies, the party apparatus usually asks for high compensation for the "divorce" or asks the companies to merge with state firms. ("Private firms jump to take 'red caps' off," China Daily, November 4, 1994.)

\footnotetext{
20 Although Walder (1995a) does not accept the "private incentive" hypothesis, he acknowledges its plausibility: "It has sometimes been documented, and is even more widely suspected, that significant numbers of village-run, and perhaps even township-run enterprises are in effect operated as family business, in which there is no clear distinction between officials' income and village revenue. This can occur when village officials grant rights to operate public industrial assets to themselves or family members or other partners on contracts that give them fixed percentage of the enterprises' profits after contractual payments to the government are made. This may also occur through embezzlement and the abuse of expensive accounts ... Unfortunately there are no reliable estimates of how widespread such 'hidden privatization' is ..."
} 


\section{Example 4: China's state firm reform and price liberalization}

The third example of the dual track approach is China's state firm reforms and price liberalization (Sachs and Woo, 1999, p. 17). By 1983, a de facto contract responsibility system (CRS) of the SOE had emerged. An SOE would sign an individually negotiated contract with its supervising agency specifying the annual amount of revenue (tax-cum-profit) to be turned over to the state, thereby supposedly giving the firm the incentive to maximize its financial surplus. However, SOEs remained subject to a soft budget constraint, being absolved of the responsibility of paying the contracted amount if the financial outcome was poor. Managers and workers colluded to rip state assets in the format of bonus and employee benefits in kinds. As a result, the state found the decline in revenue expressed as a percent of GDP to be much larger than anticipated.

In 1983, the state began to replace the CRS with an income tax. This income tax system was short-lived, however, because it not only failed to arrest the decline in revenue-GDP ratio, but state firms tried to bargain with the government over tax terms and to claim that the government determined prices, rather than their management, taking responsibility for low profit. By 1986, SOEs were reverting to an expanded CRS. Under this system, many managers set up collective firms to transfer valuable assets to them and leave all bad debt to the state firms contracted. Also, many contractors cannot honor their contracts (see Qiye Jingji, Enterprise Economy, 1995, No. 7, p. 45). This is not surprising, since according to the economics of property rights (Alchian and Demsetz, 1972), nobody has the incentive to find good contractors and to efficiently enforce contracts if nobody claims the residual rights of the state firms. The CRS was again replaced by an income tax in January 1994. As shown in Yang and $\mathrm{Ng}$ (1995, see also Sachs and Yang, 2000, chapter 8), claims to private residual rights of a firm are essential for indirectly pricing entrepreneurial services which involve prohibitively high direct pricing costs. Hence, privatization of the SOE is essential for successful reforms. Whether China's experience of state firm reform confirms this depends on empirical evidence.

As reported in Sachs and Woo (1999, pp. 19-28), the productivity performance of the SOEs remains a highly contentious issue. Some researchers see improvements, while others do not. But most writers have two important points of agreement: (1) SOE productivity growth, if any, has been lower than non-state firm productivity growth; and (2) improvements in total factor productivity (TFP), if any, are associated with quickly deteriorated financial performance of the SOEs during the reform period.

According to Bai, Li and Wang (BLW, forthcoming), TFP improvements (if any) have not increased economic welfare in China, and this is why the Chinese general public and Chinese leaders have continued to see SOE reform as a failure. BLW pointed out that TFP growth is a good index of welfare improvement only "in the context of profit-maximizing and market-oriented firms. However, for SOEs under reform, these conditions are not satisfied. In fact, this is the very reason for SOE reform. One of the important non-profit objectives of the managers is their excessive pursuit of output."

When both output and profits were included in the objective function of SOE managers, BLW found that "a higher productivity as measured by the TFP growth may actually lead to lower profitability and therefore, in many cases, lower economic efficiency." The image of some Chinese SOEs producing undesired goods, but with greater efficiency, finds some support in the aggregate data on inventories. Inventory investment in China averaged 7 percent of GDP in the 1980-93 period, compared to an average of 2 to 3 percent for the OECD countries. Only some Eastern European 
countries prior to 1990 had such high inventory investment rates. These high inventory levels suggest considerable production that is simply not marketable. In particular, the unsold inventory is counted as output of SOEs in China. Hence, estimates of TFP based on the output data are clearly overstated. Lardy (1998a, p. 206) also documents the correlation between a mountain of unsold inventories and increasing numbers of bad loans to SOEs.

Even if one believes that SOE managers in China are mainly maximizing profits, technical innovations comprise only one method of maximizing an SOE's profits. It may be financially even more rewarding for an SOE manager in China to spend time developing good relations with the state bureaucracy than increasing production efficiency. Until the 1990s, the large and medium-sized SOEs had to fulfill their production quota at below-market prices, and they received subsidized inputs in return. If the amount of subsidized inputs was high, the quota system would generate a positive rent to the enterprise. $\mathrm{Li}$ (1994) estimated that an SOE that made positive market profits on its above-quota production in the 1986-88 period received a rent that was 2.7 times that of its market profit. Bureaucratic haggling was vastly more profitable than competing in the market. Li's rent estimate may be the lower bound, because it did not include the rent that an SOE received from tax bargaining, a practice so pervasive that an SOE paid an effective income tax rate of 33 percent instead of the legal rate of 55 percent then in force.

Economists have a consensus about the financial performance of SOEs. There has been a steady increase in SOE losses since additional decision-making powers were given to SOE managers in the mid-1980s. The situation stabilized in the 1990-91 period when the state attempted to recover some of the decision-making power devolved to the SOEs. In 1992, decentralizing efforts accelerated at the initiative of local leaders after Deng Xiaoping called for faster economic reforms in order to avoid the fate of the Soviet Union. The unexpected result was that faster economic growth was accompanied by larger SOE losses. About two-thirds of the Chinese SOEs ran losses in 1992 when output growth in that year was 13 percent. These enterprise losses cannot be blamed on price controls, because price controls covered only a small proportion of SOEs in 1992. State enterprise losses have continued to accelerate since then. In the first quarter of 1996, the entire SOE sector slid into the red for the first time since the establishment of the People's Republic of China in 1949. It reported a net deficit of 3.4 billion yuan.

Some economists emphasize the "spontaneous appropriation" of firm profits by managers and workers as the most important cause for the general decline in SOE profits. With the end of the central plan and the devolution of financial decisionmaking power to the SOEs, the key source of information to the industrial bureaus regarding the SOEs were reports submitted by the SOEs themselves. This reduction in the monitoring ability of the state in a situation of continued soft budget constraints meant that there was little incentive for state-enterprise managers to resist wage demands, because their future promotion to larger SOEs was determined in part by the increases in workers' welfare during their tenure.

\footnotetext{
21 "Record loss suffered by state sector," South China Morning Post International Weekly, June 29, 1996.

${ }^{22}$ This SOE tendency to over-reward workers received official acknowledgment in 1984 when the government introduced a progressive bonus tax to control the generous dispensation of bonuses that began in 1979. An annual bonus of up to 4 months of basic wages was exempted from the bonus tax; but a fifth month bonus would require the SOE to pay a 100 percent bonus tax; a sixth month bonus would be subject to a 200 percent bonus tax, a seventh month bonus would be subject to a 300 percent bonus tax, and so forth.
} 
One of the earliest attributions of the erosion of SOE profits to the decentralizing reforms was a 1986 report by the China Economic System Reform Research Institute, which pointed out the emerging tendency of SOEs to over-consume and over-invest through various bookkeeping subterfuges. ${ }^{23}$ Woo, Hai, Jin and Fan (1994), Woo (1994), and Fan and Woo (1996) used various samples and national data to show that the sum of direct income (wages and bonuses) and indirect income (e.g. subsidies and in-kind distribution) increased more than labor productivity growth. Minami and Hondai (1995) found that since 1988, the labor share of output in the machine industry started rising with the acceleration of decentralized reforms in 1985 and exceeded the estimated output elasticity. Bouin (forthcoming) calculated that the marginal product labor of industrial SOEs increased by 5 percent in 1989-93, while the product wage of industrial SOE workers rose by 7 percent. Meng and Perkins (1996) studied the determinants of wage and labor demand in 149 industrial SOEs and 139 non-state firms in Guangzhou, Xiamen, Shenzhen, and Shanghai (four coastal economies that are marked by more intense market competition) in the 1980-92 period. Meng and Perkins found that the SOEs under decentralization reforms were maximizing income per employee (by dipping into profits) like labor-managed firms, while non-state firms were maximizing profits like capitalist firms.

Naughton (1994b) was skeptical of the excessive compensation explanation, because "the SOE wage bill, including all monetary subsidies, has remained approximately unchanged at about 5\% of GNP since 1978." There are two difficulties with this point of view. The first is that the correct test for the excessive compensation hypothesis is to normalize the SOE wage bill by value-added in the SOE sector and not by economy-wide GDP. The second difficulty is that direct cash income is only a part of the total package of labor compensation, and that the main categories of direct cash compensation have been under strict state regulation in order to control inflation and embezzlement. The wage and bonus regulations have forced the SOEs to increase workers' income through indirect means like better housing, improved transportation, new recreational facilities, benefits in kind, and study tours. 24

The financial weakness of SOEs has destabilized the macroeconomy by increasing money creation through three channels. The first channel is the monetization of the growing state budget deficits caused by the declining financial contribution from the SOE sector. SOEs paid income taxes that amounted to 19.1 percent of GDP in 1978, 6.6 percent in 1985 and 1.7 percent in 1993; and they remitted gross profits of 19.1 percent, 0.5 percent and 0.1 percent respectively (World Bank 1995, Table 7.3; and 1996b, Table 23). The second channel for money creation is the financing of mounting SOE losses by bank loans. The third channel is the disbursement of investment loans to the SOEs to make up for their shortage of internal funds to finance capacity expansion and technical upgrading.

Some economists claim that SOEs take care of social welfare for the government, and new nonstate firms have younger employees and have little burden of pension payments and other welfare benefits. Hence, a deteriorated financial performance of

\footnotetext{
23 This report has been published in English as Reynolds (1987).

24 These indirect transfers are listed under either production costs or investment expenditure financed from depreciation funds. The ingenuity of disguising extra compensation can be quite impressive. Chen (1994) reported that "in some enterprises, [workers'] shares, with promised interest rate higher than bank deposit rates in addition to fixed dividend payment, are simply a device to raise the level of wages and bonuses which have been regulated by the government to control inflation."
} 
SOEs is understandable as the size of the private sector relative to the state sector increases.

Lardy (1998a, pp. 53-57) documents the fact that the SOEs have been expanding in terms of levels of output and employment and in terms of employment share and finance share, although its output share decreases and financial performance deteriorates. In particular, most of the loans made by the monopolized state bank system go to the SOEs, and other inputs into the SOEs have been increasing. As he shows, the financial performance of state firms has deteriorated despite increasing competition and continuous market liberalization in the past two decades. The rise in liabilities relative to assets of state-owned firms, reaching an average of $85 \%$ in 1995 , is perhaps the most conclusive evidence. According to Lardy (1998a, p. 119), China's four major state banks as a group have a negative net worth and thus are insolvent. This potential financial crisis is mainly caused by the deteriorating financial performance of the SOE. He indicates that the combination of a rising savings rate and significant seignorage have provided the central government with financial resources that it has used to temporarily paper over deeply rooted structural problems. Contrary to Bai, et al (1999), this view implies that anonymous banking in China, which encourages an unusually high saving rate, is a source of a potential financial crisis rather than a driving force of China's growth.

It is notable that the original demands of the 1989 Tiananmen demonstrators were for reduction of inflation and corruption. We therefore think that the oft-given justifications for the absence of privatization in China on the grounds of preserving social stability may be overlooking the social tensions being created by the assetstripping, corruption, and macroeconomic instability caused by the unreformed ownership structure of the SOEs. (Of course, corruptly managed privatization, as in the case of natural resources in Russia, can also lead to profound inequities and social instability). He (1997, pp. 71-240) documents the large scale of corruption caused by the dual track approach to the land market, state firm reforms, and price reforms. According to her, the large scale of corruption has been so pervasive that immorality and opportunism have spread into every aspects of society. According to many Chinese whom we contacted, resentment against social injustice caused by this largescale corruption may cause a popular rebellion against the regime. But this serious potential consequence of the dual track approach has not received its deserved attention from economists outside of China.

Reports since 1995 indicate that full-scale sales of small and medium SOEs have occurred all over China. The best known example is Zhucheng city in Shandong province, which started privatizing SOEs in 1992 when two-thirds of its SOEs were losing money or just breaking even. ${ }^{26}$ Almost ninety percent of county-supervised SOEs in Zhucheng have already been privatized. The acceleration in the SOEs' conversion to joint-stock companies reflects the leadership's opinion that partial privatization through public offerings in the stock markets and through joint ventures with foreign companies would be an improvement over the contract responsibility

\footnotetext{
${ }^{25}$ The anonymous banking can protect private properties against state predation on the one hand, it protects also money laundry and associated corruption. Because of institutionalized state opportunism, Chinese government's tax collection capacity is rapidly weakening as the private sector develops. Hence, Bai, et al (1999) considers the anonymous banking, combined with control of interest rates, as an effective way for government indirectly taxing residents. But this again generates dilemma between efficiency and injustice caused by tolerance of corruption.

26 "China City Turns Into a Prototype for Privatization," Wall Street Journal, June 10, 1995. See also "Heilongjiang puts 200 firms on the block," China Daily, June 7, 1996.
} 
system. However, the corporatization of state firms in the absence of formal privatization created large scale of corruption.

The relationship between the dual track approach and corruption is best illustrated by He's documentation of two types of spontaneous privatization in China. He (1997, pp. 101-38) documents the partial privatization of state firms via joint stock companies in China during 1987-1993. ${ }^{27}$ Under the game rules wherein the rule maker, the referee, and the player are the same government agent, this spontaneous privatization involves a large scale of corruption. She identifies four types of corruption in this government insider-controlled process. The first mode of corruption is to directly allocate shares of state-owned joint stock companies to government officers who have the approval power for setting up and regulating such companies, and who have the power to allocate land, bank loans, and other important resources (He, p. 55). In the second mode, private companies are set up in Hong Kong or overseas as partners or subsidiaries of the state joint stock company. Then, via various dealings between the two firms with peculiar terms (for instance, selling at a low price and buying at high prices), state assets are transferred from the latter to the former (He, p. 60, p. 69). In the third mode, private shareholders bribe the government representatives in such joint stock companies to transfer the government shares free of charge to the former via various restructuring schemes of ownership (He, pp. 57-60). In the fourth mode, the government representative in the joint venture between the state firm and a foreign company purposely understates the value of the state asset, then gets paid by the foreign partner under the table. Finally, many real private joint stock companies have emerged during this period. But the owners of the companies must pay a very high bribe to get them registered and keep them going (i.e., getting land and other essential inputs and all kind of official approvals and permissions to avoid government expropriation and restriction of private business). A very strong patronage relationship between government officers and private firms is essential for the survival of private firms in China. ${ }^{28} \mathrm{He}$ (1997) and other Chinese scholars hold that partial privatization of state firms via joint-stock ownership was a failure. Performance of most new joint stock companies has not improved. The principle of "one share one vote" in China's Company Law is not implemented in partial privatization even after 1994 when China's Company Law was passed. Shares owned by the government have more voting rights. Insider trading and corruption are rampant. Many cases of spontaneous privatization of this kind of state holding companies, documented in He (1997), involve capital flight to overseas. ${ }^{29}$ This pattern of companies becomes a vehicle for insiders stealing state-owned assets.

He (1997, pp. 71-100), also documents many cases of spontaneous privatization of use rights of land under the dual track approach to state ownership of land and trade of land use rights. According to her, this is a large scale corruption process in which government officers who have approval power for procuring land sell their approval documents for money. Most of the money used to purchase land was from state banks. Hence, in this large scale of China's enclosurement during 1988-1994, many state bank officers who have approval rights to loans and their supervisors were involved in corruption. Again, the dual track approach creates the market for use

\footnotetext{
${ }^{27}$ There were 3800 joint stock companies in China in October, 1993 (He, 1997, p. 53).

${ }^{28}$ Chen and Zhou (1996) document many cases of large private companies that emerged in this period and state predation of private firms.

${ }^{29}$ According to Xing (1999), enormous values of errors and missing items in China's international income balance reflect the huge size of capital flight. This item was $\$ 9.8, \$ 17.8, \$ 15.6$, and $\$ 16.9$ billion in 1994, 1995, 1996, and 1997, respectively.
} 
rights of land on the one hand, and institutionalizes corruption and state opportunism on the other.

In the 1995 ranking by Transparency International of the seriousness of corruption within 41 countries, China ranked second in the extent of corruption (Sachs and Woo, 1999). Continuing corruption and misuse of state assets will further undermine public support for the existing political institutions. The adverse effect of the dual track approach may well outweigh its positive effect on raising constituencies for the reforms via buying out the vested interests.

In addition, the dual track approach generates very unequal income distribution, which is associated with inefficiency. Discrimination against rural residents institutionalized by the residential registration system creates anti-efficiency unequal income distribution between the urban and rural areas. Discrimination against inland regions institutionalized by trade privileges granted to a restricted set of coastal regions creates anti-efficiency unequal income distribution between coastal and inland regions. The growing income gap between coastal and inland provinces, documented in Jian, Sachs, and Warner (1996), and an increasing Gini coefficient not only restrict the extent of the market and retard evolution of division of labor, but also generate popular and strong resentment against the regime, which has caused a lot of protests and might cause large-scale rebellions. 30

It seems to us that China's experience with the dual track approach does not provide much new information that institutional experiments in the rest of the world did not already provide. It just verifies again that successful economic development needs not only markets, but also constitutional order and the rule of law to protect individuals' rights and provide effective checks and balances of government power. Appropriate moral codes, behavior norms, and breaking political monopoly of the ruling party are essential for the formation of the constitutional order.

\section{Trade offs between Reliability and the Positive Network Effects of Division of Labor and between Incentive Provision and Stability}

Output fall during transition in Eastern Europe and Russia is a phenomenon that many economists did not expect. Roland (2000, p. 202) reports the surprising scale of such output fall. Poland's growth rates of real GDP were -11.6 and -7.6 in 1990 and 1991. Hungary's were $-3.5,-11.9,-3.0$, and -0.9 in 1990, 1991, 1992, and 1993, respectively. Czech's corresponding figures were $-0.4,-14.2,-6.4,-0.9$, respectively. Russia's growth rates of real GDP were $-13,-19,-12,-15$ in 1991, 1992, 1993, 1994, respectively. In this section, we use the models developed in Lio (1998) and Sachs and Yang (2000, chapter 10) and a cobweb model similar to the one of Aghion, Bacchetta, and Banerjee (1998) to explain the output fall phenomenon.

The Lio model $(1996,1998)$ shows that complete insurance can increase reliability of the network of division of labor, thereby increasing the equilibrium level of division of labor and related aggregate productivity. Prior to the reforms, the Soviet Union and other socialist countries established a large network of division of labor by

\footnotetext{
${ }^{30}$ China's Gini coefficient increased from 0.2 in 1978 to .433 in 1994 (He, 1997, p. 257). According to her, the official Gini coefficient in 1994 understated inequality because of the hidden illegal income of the rich. She cites one nonofficial estimate of the Gini coefficient as 0.59 in 1995. In contrast, Taiwan's Gini coefficient decreased from .53 in the 1950 s to 0.33 in the 1970 s during the takeoff stage of economic development (Fei, Ranis, and Kuo, 1979).
} 
mimicking the capitalist industrialization pattern. Each state in the socialist block specializing in a sector supplied to all of other states and bought goods from each of other specialized sectors in other states. For instance Ukraine specialized in producing grain, Czech specialized in producing locomotives and other engines, and East Germany specialized in producing machine tools. This large network of division of labor would have very low reliability in the absence of insurance. Hence, an implicit complete insurance system was developed in the socialist countries. There was complete employment insurance, pension insurance, medical insurance, trade insurance, and so on. Each state firm was insured for all goods it produced in the sense that the central planner would buy all of them. Although this complete insurance generated a great deal of moral hazard, it provided reasonably high reliability of the large network of division of labor.

As the Soviet Union broke down, the complete trade insurance between the exsocialist countries disappeared. The reliability of the large network of division of labor established by the central planning system in the 1950s, of course decreased exponentially in the new reform era before the market for insurance was developed. As Roland (2000) suggests, the major reason for output fall is the break of the trade connection between ex-socialist countries. From the model in Yang and $\mathrm{Ng}$ (1993, chapter 11), we have learned that there is a trade off between deepening the relationship with the incumbent trade partner and broadening potential trade connections. Under a socialist system, the transaction cost coefficient for broadening potential relationships is extremely great because of the rigid hierarchical structure of the central planning system. Hence, there is not much room for trading off a large number of potential partners against a deep incumbent relationship in order to increase the reliability of the network of division of labor. As the break-up of the Soviet Union and the socialist block cut the incumbent trade connection between many highly specialized firms, the entire network of division of labor of course failed to work. According to Lio's theory, it would be very surprising if there were no such mass output fall after the break-up of the Soviet Union and the socialist block.

The Lio model (1996, see also Sachs and Yang, 2000, example 10.6) shows that there is a trade off between incentive provision, which can be increased by incompleteness of insurance, and reliability gains of the network of division of labor, which can be increased by insurance. This trade off implies that focusing on incentive provision and ignoring the positive contribution of the implicit insurance to the network reliability of division of labor may not achieve the efficient balance of the trade off. The development of various insurance markets is essential for the success of privatization reforms.

The recent Russian financial crisis was correlated with high international capital mobility. Aghion, Bacchetta, and Banerjee (1998) develop a cobweb model to explain why great capital mobility in a developed international financial market may decrease market stability. Their story runs as follows. If there is a time lag between economic performance and financial signals, there would be a trade off between incentive provision, which can be increased by sensitivity of feedback between signals and players' actions, and stability of the feedback process, which will be decreased by increasing the sensitivity. A feedback system that is not sensitive to signals (as in a socialist system) would fail to provide enough incentive for economic development. But a too-sensitive feedback process will generate nonconvergent fluctuation, an explosion, or a chaotic process. In the model of Aghion et al, the degree of feedback sensitivity is represented by a feedback sensitivity coefficient in a difference equation that relates signals to players' actions via a time lag between the two variables. High capital 
mobility in a developed international financial market is associated with a large value of the coefficient. This high mobility implies that any trivial positive signal can attract capital from all countries in the world, and thereby create a huge inflow of capital within a very short period of time. Any trivial negative signal can have a huge opposite effect, which can generate a panic flight of capital (explosion or chaos in the nonlinear difference equation).

This trade off between incentive provision and stability implies that it is not efficient to have an extremely high power incentive. Russia liberalized its capital account prior to privatization reforms. This significantly increased the sensitivity of the feedback mechanism. Privatization reforms further increased the sensitivity, which is good for providing incentives, but not good for stability. Of course, corruption and money laundry were the source of negative signals. Without the moral hazard caused by opportunism, sensitive feedback itself may not make trouble, just like what happens to the highly developed financial market in Taiwan and in Western Europe. But moral hazard itself is not enough to explain Russia's and South Korea's financial crises, since moral hazard in China, which was not greatly affected by the Asian financial crisis, is even greater than in Russia and South Korea. Some economists explain the financial crises in Russian and Asia using the conventional models of moral hazard. But the models cannot explain why the crises occurred when liberalization and privatization were implemented. Lio's models $(1996,1998)$ and the model of Aghion et al show that the trade offs between reliability, transaction costs, and economies of division of labor and between incentive provision, sharing risk, and stability can explain the crises better. In the rest of this section, we use a cobweb model to illustrate the story behind the model of Aghion et al.

Example 5: A cobweb model with the trade off between sensitive incentive and stability.

Consider the Smithian model in Sachs and Yang (2000, example 4.2). An individual's decision problem based on the CES utility function is:

$$
\begin{aligned}
& \text { Max: } u=\left[\left(x^{c}\right)^{\rho}+\left(y^{c}\right)^{\rho}\right]^{1 / \rho} \quad \text { (utility function) } \\
& \text { s.t. } \quad x^{c} \equiv x+k x^{d} \quad y^{c} \equiv y+k y^{d} \quad \text { (definition of quantities to consume) } \\
& x+x^{s}=l_{x}{ }^{a} \quad y+y^{s}=l_{y}{ }^{a} \quad \text { (production function) } \\
& l_{x}+l_{y}=1 \quad \text { (endowment constraint) } \\
& p_{x} x^{s}+p_{y} y^{s}=p_{x} x^{d}+p_{y} y^{d} \quad \text { (budget constraint) }
\end{aligned}
$$

where $x$ and $y$ are respective amounts of the two goods self-provided, $x^{s}$ and $y^{s}$ are respective quantities of the two goods soled, $x^{d}$ and $y^{d}$ are respective quantities purchased, $l_{x}$ and $l_{y}$ are respective quantities of labor allocated to the production of the two goods. $p_{i}$ is the price of good $\mathrm{i}$, which is a given parameter in a Walrasian regime. The optimum decisions in the various configurations are summarized in the following Table.

\section{Table 1: Corner Solutions in Four Configurations}

\begin{tabular}{c|l|l|l|c}
\hline $\begin{array}{l}\text { Config } \\
\text { uration }\end{array}$ & $\begin{array}{l}\text { Quantities self- } \\
\text { Provided }\end{array}$ & $\begin{array}{l}\text { supply } \\
\text { functions }\end{array}$ & $\begin{array}{l}\text { demand } \\
\text { functions }\end{array}$ & $\begin{array}{l}\text { indirect utility } \\
\text { function } \mathrm{u}(\mathrm{p})\end{array}$ \\
\hline $\mathrm{A}$ & $x=y=0.5^{a}$ & 0 & 0 & $2(1-\rho a) / \rho$ \\
\hline$(\mathrm{x} / \mathrm{y})$ & $x=\left[1+(k / p)^{\rho /(1-\rho)}\right]^{-1}$ & $x^{s}=\left[1+(p / k)^{\rho /(1-\rho)}\right]^{-1}$ & $y^{d}=x^{s} / p$ & {$\left[1+(k / p)^{\rho /(1-\rho)}\right]^{(1-\rho) / \rho}$}
\end{tabular}




\begin{tabular}{l|l|l|l|l}
\hline$(\mathrm{y} / \mathrm{x})$ & $y=\left[1+(k p)^{\rho /(1-\rho)}\right]^{-1}$ & $y^{s}=\left[1+(k p)^{-\rho /(1-\rho)}\right]^{-1}$ & $x^{d}=p y^{s}$ & {$\left[1+(k p)^{\rho /(1-\rho)}\right]^{(1-\rho) / \rho}$} \\
\hline
\end{tabular}
where $p \equiv p_{y} / p_{x}$ and $\rho \in(0,1)$. Configuration $\mathrm{A}$ is autarky where each individual selfprovides $\mathrm{x}$ and $\mathrm{y}$. Configuration $(\mathrm{x} / \mathrm{y})$ denotes that an individual produces and sells good $\mathrm{x}$ and buys good $\mathrm{y} .(\mathrm{y} / \mathrm{x})$ denotes that an individual produces and sells good $\mathrm{y}$ and buys good $\mathrm{x}$. The corner equilibrium relative price in structure $\mathrm{D}$ consisting of configurations $(\mathrm{x} / \mathrm{y})$ and $(\mathrm{y} / \mathrm{x})$ is $p=1$, given by the utility equalization between the two configurations.

We now introduce the discrete time dimension into the model. There is a oneperiod time lag between changes of the relative number of individuals choosing professional occupations $(\mathrm{x} / \mathrm{y})$ and $(\mathrm{y} / \mathrm{x})$ in response to the difference in utility between the two occupations. Hence,

$$
M_{x}(t)-M_{x}(t-1)=\beta\left[u_{x}(t-1)-u_{y}(t-1)\right]
$$

where $t$ denotes the time period and $\beta$ is the sensitivity coefficient of changes in the number of specialist producers of $\mathrm{x}$ in response to the difference in utility between two occupation configurations. $M_{i}(t)$ is the number of specialist producers of good i in period t. The indirect utility function $\mathrm{u}_{\mathrm{i}}$ for a specialist producer of good $\mathrm{i}$ is given in the above table. Since $M_{x}(t)+M_{y}(t)=M$ where population size $M$ is a given parameter, changes in $\mathrm{M}_{\mathrm{x}}(\mathrm{t})$ are proportional to changes in $M_{y}(\mathrm{t})$ in the opposite direction. For simplicity, we assume that $M=1$. Further, there is a one-period time lag between changes of relative price of good $\mathrm{y}$ to good $\mathrm{x}$ in response to changes in excess demand for good $y$. Hence,

$$
p(t+1)-p(t)=\alpha\left[M_{x}(t) y^{d}(t)-M_{y}(t) y^{s}(t)\right]
$$

where $M_{y}(t)=1-M_{x}(t)$ and $y^{d}(t)$ and $y^{s}(t)$ are given in Table $1 . \alpha$ is the sensitivity coefficient of changes of relative price in response to excess demand for good $y$. The (1) and (2) constitute a second order nonlinear system of difference equations in $p$ and $M_{x}$. Assume that the initial state of the system is given by $M_{x}(0)=M_{0}, p(0)=p_{0}$, and $p(1)=p_{1}$. Then, the dynamics and comparative dynamics of this system can be given by simulations on the computer. Figure 1(a) gives the results of the simulations for $\alpha$ $=0.6, \beta=0.2, \rho=0.6, k=0.6, M_{0}=0, p_{0}=0.2$, and $p_{1}=0.21$. In panel (b), $\alpha$ is increased to 1.61 and other parameters are unchanged. In panel (c), $\alpha$ is increased to 1.62 and other parameters are unchanged. In panel (d), all parameter values are the same as in panel (a) except that $\beta$ increases from 0.2 to 0.3. In panel (e), all parameter values are the same as in panel (a) except that $\mathrm{k}$ increases from 0.6 to 0.601 .

A comparison of the time paths of relative price $p$ and the numbers of $x$ specialists $M$ in panels (a) and (b) shows that as the feedback sensitivity parameter $\alpha$ increases from 0.6 to 1.61 , the convergence of the feedback process to the static equilibrium (steady state, $p=1$ and $M_{x}=0.5$ ) becomes faster. Panel (c) shows that as the sensitive coefficient $\alpha$ reaches the threshold level, 1.62, the number of specialist producers of $\mathrm{x}$ becomes negative after several rounds of feedback. A comparison between panels (b) and (d) shows a similar result of an increase of value of sensitivity parameter of $\beta$ from 0.2 to 0.3 with unchanged $\alpha=0.61$. The negative number of specialists in an occupation is not feasible. Hence, this implies a breakdown of the division of labor and all individuals have to choose autarky, even if the static equilibrium is the division of labor (utility in the structure with the division of labor is 
higher than in autarky). This panic rush of individuals from the occupation configuration producing $\mathrm{x}$ to that producing $\mathrm{y}$ as $M_{x}$ tends to 0 looks like the panic rush of investors from one country to the other in a highly integrated world market with a very high level of international division of labor. A comparison between panels (b) and (e) shows that an increase in the trading efficiency coefficient $\mathrm{k}$ has the same effect of an increase in feedback sensitivity parameters. Also, as k reaches a threshold, the system will overshoot and never reach the steady state. 

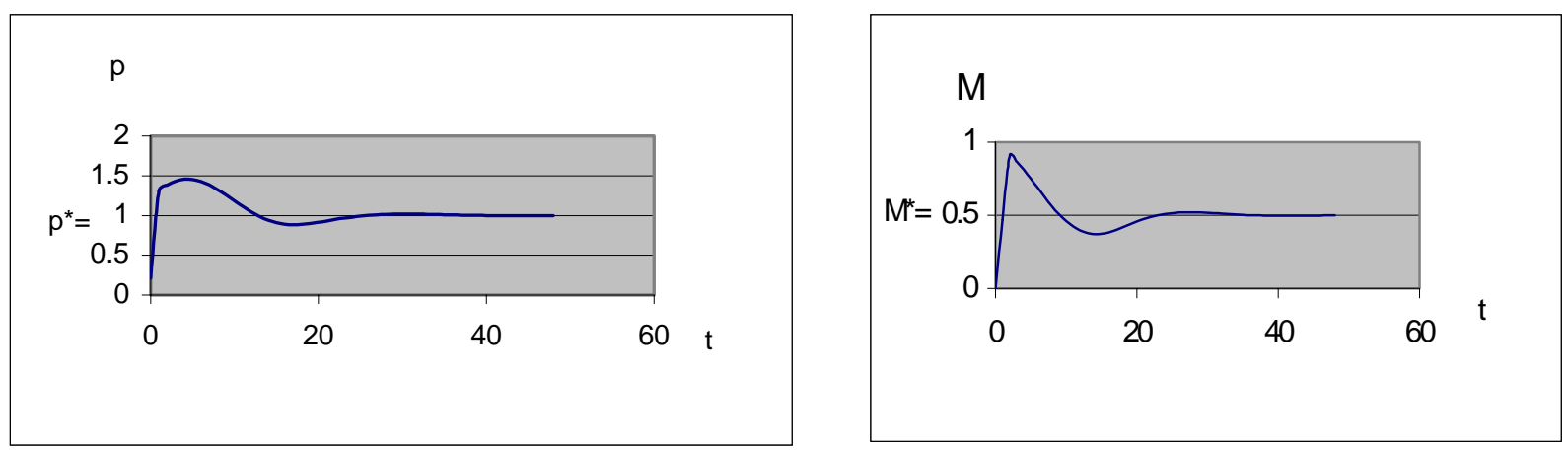

$\alpha=0.6, \beta=0.2, \rho=0.6, k=0.6$
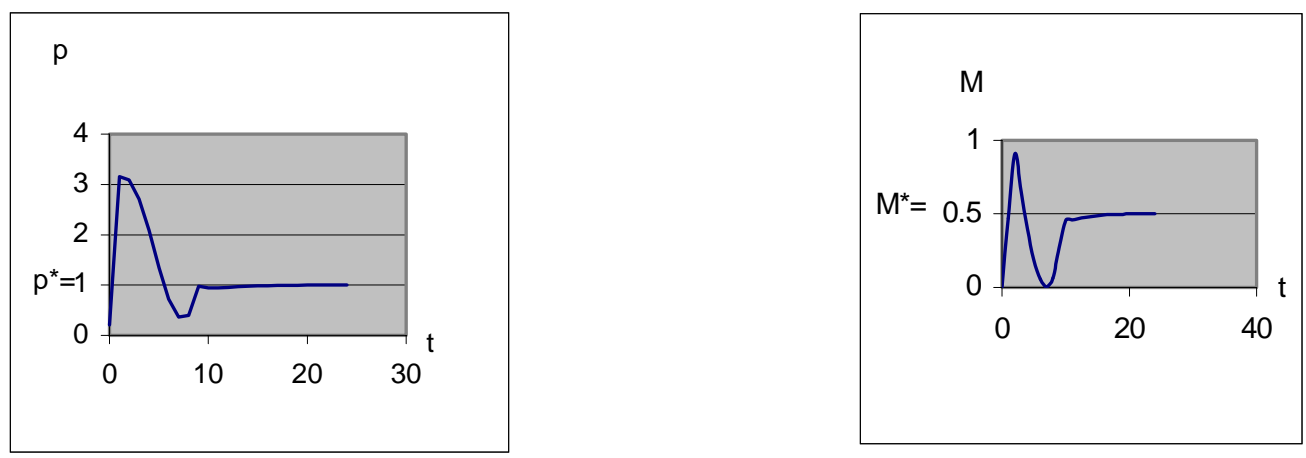

(b) $\alpha=1.61, \beta=0.2, \rho=0.6, k=0.6$
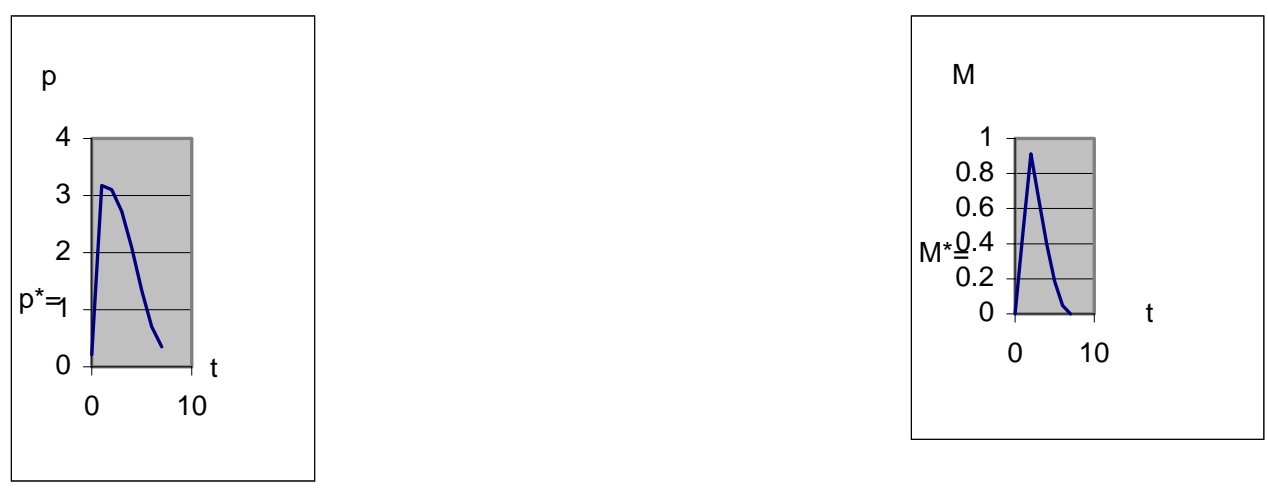

(c) $\alpha=1.62, \beta=0.6, \rho=0.6, k=0.6$
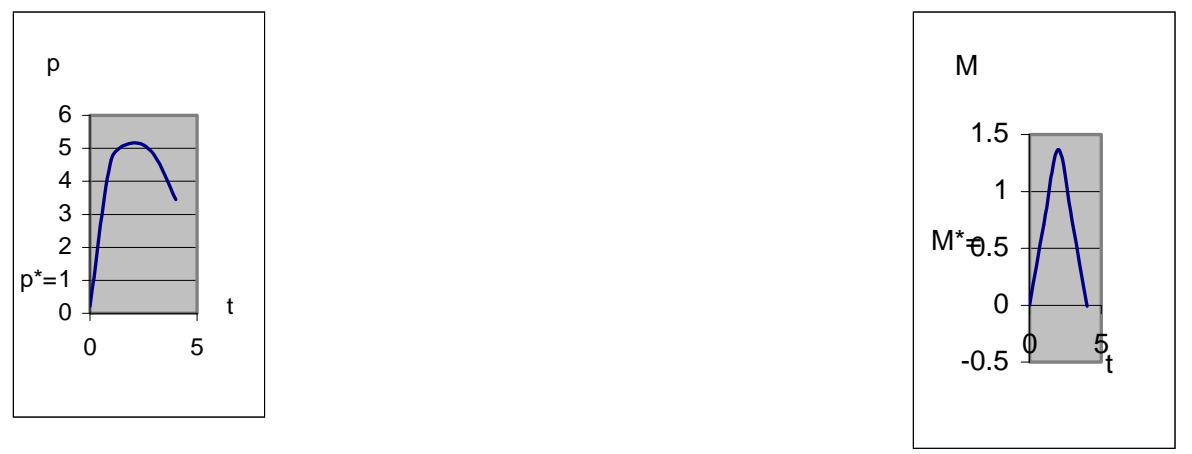

(e) $\alpha=1.61, \beta=0.2, \rho=0.6, k=0.601$ 

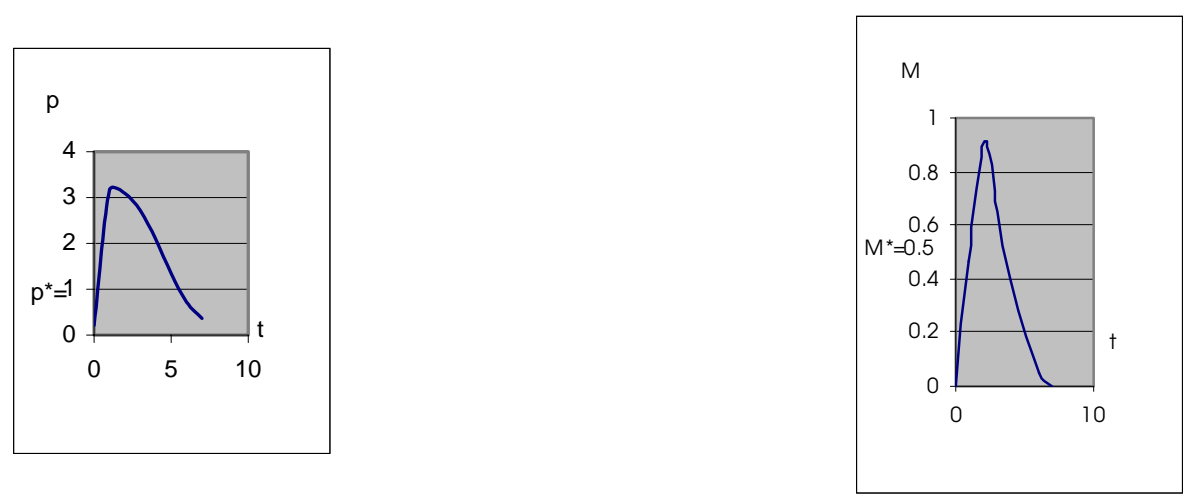

(d) $\alpha=1.61, \beta=0.3, \rho=0.6, k=0.6$

\section{Figure 1: Trade off Between Sensitive Incentive and Stability of Feedback Mechanism}

The results are very intuitive. If the system starts from a non-equilibrium state, then an occupation generates more utility than the other, so that individuals will shift from the latter to the former. This will adjust aggregate demand and supply of a traded good and thereby excess demand for this good. The relative price will change in response to the change in excess demand. The indirect utility functions in different occupations will change in response to this change in relative price. This will again cause changes in the relative number of specialists in the two occupations if the steady state is yet to be achieved. In this feedback process, the more sensitive the feedback, the faster the convergence of fluctuations toward the steady state. But if the feedback is too sensitive, the system may overshoot, so that the steady state can never be reached. A larger trading efficiency coefficient has an effect similar to that of a larger feedback sensitivity coefficient. It can speed up the convergence of the feedback before a threshold is reached. A very high trading efficiency may generate overshoot that paralyzes the feedback mechanism.

This model can be used to explain fluctuations of excess demand for professionals, such as lawyers and accountants, with a time lag between education and professional work. Also, it can explain the financial crisis caused by liberalization reforms that increased sensitivity coefficients or trading efficiency by raising the mobility of capital, goods, and labor.

Liberalization and privatization reforms will increase feedback sensitivity coefficients or the trading efficiency coefficient. This will make the convergence of the economic system toward equilibrium faster, but will also increase the risk of overshot that reduces the realized level of division of labor and related trade. It can be shown that for the same feedback sensitivity coefficient and trading efficiency, the larger the initial difference between value of price and its static equilibrium level, the more likely the feedback system may break down by overshot. This explains why Taiwan was not greatly impacted by the Asian financial crisis.

Taiwan implemented liberalization and privatization reforms of its financial sector before liberalizing its capital account. This ensured a low moral hazard caused by state monopoly of the financial sector. This implies that the initial difference between prevailing market price and its static equilibrium level was not great when feedback sensitivity was raised by liberalization reforms. China had very high moral hazard. But since it had a very small feedback sensitivity coefficient due to the 
government's tight control of the capital account, it was not greatly affected by the Asian financial crisis either. In contrast, South Korea liberalized its capital account before great moral hazard in its state monopolized financial system was significantly reduced. Hence, the initial difference between market price and its static equilibrium level, which relates to moral hazard, and the feedback sensitivity and trading efficiency coefficients, which relate to the openness of the financial market, are two major determinants of the trade off between incentive provision and stability. Hence, the different cases of Taiwan, China, and South Korea can all be explained by the cobweb model. The story suggests that the sequence of liberalization and privatization reforms makes a difference. In the literature of engineering, the degree to which the feedback system achieves the efficient balance of the trade off between feedback sensitivity and stability is referred to as feedback quality. The major task in macroeconomic policy-making is to raise feedback quality.

\section{Concluding Remarks}

This paper investigates the relationship between economic reforms and constitutional transition, which has been neglected by many transition economists. It is argued that assessment of reform performance might be very misleading if it is not recognized that economic reforms are just a small part of large scale of constitutional transition. Rivalry and competition between states and between political forces within each country are the driving forces for constitutional transition. We use Russia as an example of economic reforms associated with constitutional transition and China as an example of economic reforms in the absence of constitutional transition to examine features and problems in the two patterns of transition. It is concluded that under political monopoly of the ruling party, economic transition will be hijacked by state opportunism. Dual track approach to economic transition may generate very high long-term cost of constitutional transition that might well outweigh its short-term benefit of buying out the vested interests. 


\section{References}

Aghion, P., Bacchetta, P., and Banerjee, A. (1998): "Capital Markets and the Instability of Open Economies", Working paper, presented at Harvard University and MIT Growth and Development Seminar.

Alchian, A. and Demsetz, H. (1972), "Production, Information Costs, and Economic Organization", American Economic Review, 62, 777-95.

Bai, Chong-En, David D. Li, and Yingyi Qian, Yijiang Wang. (1999)."Anonymous Banking and Financial Repression: How Does China's Reform Limit the Government's Predation without Reducing Its Revenue?" Mimeo, Stanford University.

Bardhan, P. and Roemer, J. eds. (1993), Market Socialism, the Current Debate, Oxford University Press.

Barzel, Y. (1997), "Property Rights and the Evolution of the State," memeo. and "Third-party Enforcement and the State," memeo. Department of Economics, University of Washington.

Beik, Paul H. ed. (1970), The French Revolution. New York, Harper \& Row.

Blanchard, Olivier. (1997). Economics of Post-Communism Transition, Oxford University Press.

Bouin, Olivier. (forthcoming) "Financial Discipline and State Enterprise Reform in China in the 1990s," in Olivier Bouin, Fabrizio Coricelli and Francoise Lemoine (ed.), Different Paths to a Market Economy: China and European Economies in Transition, OECD, Paris.

Bruun, O. (1993), Business and Bureaucracy in a Chinese City, Chinese Research Monographs No. 43. Berkeley, Institute of East Asian Studies, University of California.

Buchanan, James M. (1989), Explorations into Constitutional Economics. College Station, Texas A\&M University Press.

Burke, Edmund, (1790), Reflections on the French Revolution. ed. by W. Alison Phillips and Catherine Beatrice Phillips. Cambridge, Cambridge University Press, 1912.

Burtless, Gary (1995), "International Trade and the Rise in Earnings Inequality." Journal of Economic Literature. 33, 800-16.

Byrd, W. (1983), "Enterprise-Level Reforms in Chinese State-Owned Industry", American Economic Review, No. 73, pp. 329-32.

Byrd, W. (1988), "The Impact of the Two-Tier Plan Market System in Chinese Industry", Journal of Comparative Economics, Vol. 11, No. 3, September 1987, pp. 295-308. Reprinted in Reynolds, Bruce L., Chinese Economic Reform: How Far, How Fast?, Academic Press, London.

Byrd, William. (1991).The Market Mechanism and Economic Reforms in China. New York: M.E. Sharpe.

Byrd, W. and Tidrick, G. (1987), "Factor Allocation and Enterprises Incentives", in Tidrick, Gene and Chen, Jiyuan (eds), China's Industrial Reform, New York, Oxford University Press.

Chang, Chun; and Yijiang Wang. (1994). "The Nature of the Township Enterprises." Journal of Comparative Economics, 1994, 19, pp. 434-452.

Che, Jiahua (1999) "From the Grabbing Hand to the Helping Hand", Working Paper, Department of Economics, University of Notre Dame.

Chen, Aimin (1994), "Chinese Industrial Structure in Transition: The Emergence of Stock-offering Firms," Comparative Economic Studies, Vol. 36, No. 4, Winter, pp. 1-19.

Chen, Yinan and Zhou, Zhiren (eds) (1996) Chuangye Zhifu Bushi Mong (It is not a Dream to Make a Fortune from Entrepreneurship), Hainan International News Center.

Cheng, T. (1991): "The Present and Future of China's Residential Registration System". Ph.D. Dissertation, Department of Sociology, North-East University.

Cheung, S. (1974), "A Theory of Price Control," Journal of Law and Economics, 17, 53-71.

Cheung, Steven N. S. (1996), "A Simplistic General Equilibrium Theory of Corruption," Contemporaty Economic Policy, 14, 1-5.

Cook, Linda (1993). The Soviet Social Contract and Why It Failed: Welfare Policy and Workers' Politics from Brezhnev to Yeltsin, Harvard University Press, Cambridge, MA.

Crafts, N. (1997), "Endogenous Growth: Lessons for and from Economic History." D. Kreps and K. Wallis eds. Advances in Economics and Econometrics: Theory and Applications, Vol. II. Cambridge, Cambridge University Press.

Deane, Phyllis and Cole, William (1967), British Economic Growth, Cambridge, Cambridge University Press.

Dernberger, Robert. (1988) "Financing China's Development: Needs, Sources and Prospects," in Robert Dernberger and Richard Eckaus, Financing Asian Development 2: China and India, University Press of America, pp.12-68. 
Dewatripont, Mathias; and Gérard Roland.(1996), "Transition as a Process of Large Scale Institutional Change," in David Kreps and Kenneth Wallis (eds.), Advances in Economics and Econometrics: Theory and Applications, Cambridge: Cambridge University Press.

Ding, Guoxiang, Yan, Qingzeng, and Yang, Xun, eds. (1995), Zhongguo Nongchun Gaige Jishi (A Bibliographical Record of Events in China's Rural Reform), Shanxi Economic Publishing House.

Fan, Gang and Wing Thye Woo (1996), "State Enterprise Reform as a Source of Macroeconomic Instability," Asian Economic Journal, November.

Fang Weizhong ed. (1984), Jinji Dashi Ji (Major Economic Events in the People's Republic of China, 1949-1980), Beijing, Chinese Social Science Press.

Friedman, M. (1962), Capitalism and Freedom, Chicago: The University of Chicago Press.

Furubotn, E. and Pejovich, S. (eds.) (1974), The Economics of Property Rights. Cambridge, Mass.: Ballinger Publishing Company.

Granick, D. (1990), Chinese State Enterprises: A Regional Property Rights Analysis, Chicago, University of Chicago Press.

Gray, Cheryl and Hendley, Kathryn (1997), "Developing Commercial Law in Transition Economies: Examples from Hungary and Russia." in J. Sachs and K. Pistor eds. The Rule of Law and Economic Reform in Russia, Westview Press.

Hayek, F. (1940), "Socialist Calculation III: The Competitive 'Solution'," Economica, 7, 125-49.

Hayek, F. (1944), The Road to Serfdom, Chicago, University of Chicago Press.

Hayek, F. (1960), The Constitution of Liberty, Chicago, University of Chicago Press.

Hayek, F. (1988), The Fatal Conceit: The Errors of Socialism, Chicago, University of Chicago Press.

He, Qinglian (1997), The Primary Capital Accumulation in Contemporary China, Mirror Book, Hong Kong.

Hellman, Joel (1997, p.56), "Constitutions and Economic Reforms in the Post-Communist Transitions." in Sachs and Pistor The Rule of Law and Economic Reform in Russia, Boulder, Westview Press.

Hua, Sheng, Zhang, Xuejuen, and Lo, Xiaopen (1988), "Ten Years in China's Reform: Looking Back, Reflection, and Prospect," Economic Research, No 9, 11, 12, Beijing.

Huang, Z. (1993), "Current Development of the Private Firms in the Mainland China," Economic Outlook, Vol. 8. No. 32, 87-91

Jian, Tianlun, Jeffrey Sachs and Andrew Warner, (1996), "Trends in Regional Inequality in China," China Economic Review, Vol. 7 No. 1, Spring, pp. 1-21.

Jin, Hehui; and Yingyi Qian. (1998),"Public vs. Private Ownership of Firms: Evidence from Rural China." Quarterly Journal of Economics, August 1998, 113(3), pp. 773-808. 52

Johnson, D. Gale, (1994), "Does China Have a Grain Problem?" China Economic Review, Vol. 5 No. 1, pp. 1-14.

Kornai, J. (1980), Economics of Shortage, Amsterdam: North-Holland.

Kornai, J. (1991), The Road to a Free Economy, New York: Norton.

Kornai, J. (1992), The Socialist System: The Political Economy of Communism, Princeton, Princeton University Press.

Kornai, Janos. (1986),"The Hungarian Reform Process: Visions, Hopes, and Reality." Journal of Economic Literature, December 1986, 24, pp. 1687-1737.

La Porta, R., Lopez-de-Silanes, F., Shleifer, A., and Vishny, R. (forthcoming), "The Quality of Government", Journal of Law, Economics and Organization.

Lange, J. and F. Taylor, (1964), On the Economic Theory of Socialism. New York: McGraw Hill.

Lardy, Nicholas, (1998). China's Unfinished Economic Revolution, The Brookings Institution.

Lau, L. and Song, D-H. (1992), "Growth versus Privatization: An Alternative Strategy to Reduce the Public Enterprise Sector: The Experience Taiwan and South Korea", Working Paper, Department of Economics, Stanford University.

Lenin, V. (1939), Imperialism, the Highest Stage of Capitalism, New York, International Publishers.

Li, David (1994), "The Behavior of Chinese State Enterprises under the Dual Influence of the Government and the Market," University of Michigan, manuscript.

Li, Junhui (1999), "Shunde de Zhuangzhi (The Transformation of the Ownership System in Shunde County)," Economic Highlights, No. 36, p. 3.

Li, Wei (1997). "The Impact of Economic Reform on the Performance of Chinese State Enterprises, 1980-1989."Journal of Political Economy, 105(5), 1081-1106.

Lin, J. Y. (1998), "The Current State of China's Economic Reforms," in James Dorn, eds. China in the New Millennium: Market Reforms and Social Development, Washington, D.C., CATO Institute.

Lio, M. (1996), Three Assays on Increasing Returns and Specialization: A Contribution to New Classical Microeconomic Approach, Ph.D. Dissertation, Department of Economics, the National Taiwan University. 
Lio, M. (1998), “Uncertainty, Insurance, and Division of Labor,” Review of Development Economics, 2, 76-86.

Liu, Yia-Ling, (1992), "Reform From Below: The Private Economy and Local Politics in the Rural Industrialization of Wenzhou," China Quarterly, 130, 293-316.

Luo, Xiaopeng. (1994), "Gaige yu Zhongguo Dalude Denji Chanquan (Reforms and Property Rights based on Ranking in Mainland China", Modern China Studies, No. 41, 31-45.

Mao, Yushi (1999), "Zhengfu Ruhe Bangzu Qiye He Bangzu Jiuye (How Can the Government Assist Firms and Employment)?" Economic Highlights, No. 37, p. 1.

Mao, Zedong (1977a), Selected Works of Mao Zedong, Volume 5. Beijing: People's Press.

Mao, Tse-tung (1977b), A Critique of Soviet Economics, Translated by Moss Roberts, annotated by Richard Levy, with an introduction by James Peck. New York, Monthly Review Press.

Maskin, Eric and Chenggang Xu (1999), "Soft Budget Constraint Theories: From Centralization to the Market", Working Paper, Department of Economics, Harvard University.

McMillan, John. (1996), "Markets in Transition," in David Kreps and Kenneth Wallis (eds.), Advances in Economics and Econometrics: Theory and Applications, Cambridge: Cambridge University Press.

Men Qinguo (1988), " On the Ownership Structure of Modern Corporation," Young Economists Forum, No 4, Tianjin.

Meng, Xin and Frances Perkins, (1996), "The Destination of China's Enterprise Reform: A Case Study from a Labor Market Perspective," Australian National University, August.

Minami, Ryoshin and Susumu Hondai, (1995), "An Evaluation of the Enterprise Reform in China: Income Share of Labor and Profitability in the Machine Industry," Hitotsubashi Journal of Economics, Vol. 36, No. 2, December, pp. 125-143.

Mitchell, B. R. (1998), International historical statistics : Europe, 1750-1993. London, Macmillan Reference; New York, N.Y., Stockton Press

Mokyr, Joel (1990) The Lever of Richs: Technological Creativity and Economic Progress, New York, Oxford University Press.

Mokyr, Joel (1993) (ed.) The British Industrial Revolution, An Economic Perspective, Boulder, Westview Press.

Mokyr, Joel, (1993), "The New Economic History and the Industrial Revolution," in Mokyr, J. ed. The British Industrial Revolution: An economic perspective, Boulder and Oxford: Westview Press.

Mueller, M. (1998), "China's Telecommunications Sector and the WTO: Can China Conform to the Telecom Regulatory Principles?" in James Dorn, eds. China in the New Millennium: Market Reforms and Social Development, Washington, D.C., CATO Institute.

Naughton, Barry, (1994a), "Chinese Institutional Innovation and Privatization from Below," American Economic Review, Vol. 84 Vol. 2, May, pp. 266-270.

Naughton, Barry, (1994b), "What is Distinctive about China's Economic Transition? State Enterprise Reform and Overall System Transformation," Journal of Comparative Economics, Vol. 18, No. 3, June, pp. 470-490.

Nee, V. and Sijin, S. (1993), "Local Corporatism and Informal Privatization in China's Market Transition", Working Paper on Transitions from State Socialism No. 93-2. Einaudi Center for International Studies, Cornell.

Nee, Victor, (1996), "Changing Mechanisms of Stratification in China," American Journal of Sociology, Vol. 101 No. 4, January, pp.908-949.

Nettels, Curtis (1962), The Emergence of a National Economy, 1775-1815, New York.

$\mathrm{Ng}, \mathrm{Y}-\mathrm{K}$. and Yang, X. (1997): "Specialization, Information, and Growth: a Sequential Equilibrium Analysis". Review of Development Economics. 1, 257-74.

Nolan, Peter, (1993), State and Market in the Chinese Economy: Essays on Controversial Issues, MacMillan, London.

North, D. (1994), "Economic Performance through Time," American Economic Review. 84, 359-68.

North, Douglass and Weingast, Barry (1989), "Constitutions and Commitment: The Evolution of Institutions Governing Public Choice in Seventeenth-Century England," Journal of Economic History, XLIX, pp 803-32.

North, Douglass. (1997), "The Contribution of the New Institutional Economics to an Understanding of the Transition Problem." WIDER Annual Lectures, March.

Nussbaum, Frederick (1925) "American Tobacco and French Politics, 1783-1789," Political Science Quarterly, 40, 501-503.

Oi, J. (1986), "Commercializing China's Rural Cadres." Problems of Communism, 35, 1-15.

Oi, Jean (1995), "The Role of the Local Government in China's Transitional Economy," China Quarterly. 144, 1132-49. 
Oi, Jean. (1992),"Fiscal Reform and the Economic Foundations of Local State Corporatism in China." World Politics, October, 45(1).

Olson, Mancur (1982), The Rise and Decline of Nations: Economic Growth, Stagflation, and Social Rigidities. New Haven, Yale University Press.

Owen, T. (1997), "Autocracy and the Rule of Law in Russian Economic History," in J. Sachs and K. Pistor eds. The Rule of Law and Economic Reform in Russia, Westview Press.

Pei, M. (1998), "The Growth of Civil Society in China." in James Dorn, eds. China in the New Millennium: Market Reforms and Social Development, Washington, D.C., CATO Institute.

Peng, Yusheng, (1992), "Wage Determination in Rural and Urban China: A Comparison of Public and Private Industrial Sectors," American Sociological Review, Vol. 57 No. 2, April, pp. 198-213.

Perkins, D. (1988), "Reforming China's Economic System", Journal of Economic Literature, Vol. XXVI, pp. 601-45.

Perkins, D., ed. (1977), Rural Small-Scale Industry in China, Berkeley, University of California Press.

Perkins, Frances, Zheng Yuxing and Cao Yong, (1993), "The Impact of Economic Reform on Productivity Growth in Chinese Industry: A Case of Xiamen Special Economic Zone," Asian Economic Journal, Vol. 7, No. 2, pp. 107-146.

Philips, Ulrich (1929), Life and Labor in the Old South, Boston, Little, Brown, and Company.

Pilon, Roger (1998), "A Constitution of Liberty for China", China in The New Millennium: Market Reforms and Social Development, CATO Institute, Washington, D.C.

Ping, Xinqiao (1988), "The Reform of the Ownership System, Property Rights, and Management,"

Pipe, R. (1999), Property and Freedom, New York, Alfred Knopf.

Pistor, K. (1997), "Company Law and Corporate Governance in Russia," in J. Sachs and K. Pistor eds. The Rule of Law and Economic Reform in Russia, Westview Press.

Prosterman, Roy, Tim Hanstad and Ping Li, (1996), "Can China Feed Itself?" Scientific American, November, pp. 90-96.

Qian, Y. (1994a), "Incentives and Loss of Control in an Optimal Hierarchy", Review of Economic Studies, 61(3), 527-44.

Qian, Y. (1994b), "A Theory of Shortage in Socialist Economies based on the 'Soft Budget Constraint' ", American Economic Review, 84, 145-56.

Qian, Y. (forthcoming), "The Process of China's Market Transition (1978-98): The Evolutionary, Historical, and Comparative Perspectives." Journal of Institutional and Theoretical Economics.

Qian, Yingyi, (1999), "The Institutional Foundations of China's Market Transition", Annual Bank Conference on Development Economics.

Qian, Yingyi; and Barry R. Weingast. (1997), "Federalism As a Commitment to Preserving Market Incentives." Journal of Economic Perspectives, Fall, 11(4), pp. 83-92.

Qian, Yingyi; and Gérard Roland. (1998), "Federalism and the Soft Budget Constraint." American Economic Review, December, 88(5), pp. 1143-1162.

Qian, Yingyi; Gérard Roland; and Chenggang Xu. (1999)"Coordinating Changes in M-form and Uform Organizations." Mimeo, Stanford University.

Rawski, Thomas, (1986), "Overview: Industry and Transport," in U.S. Congress, Joint Economic Committee, China's Economy Looks Toward the Year 2000: Volume 1. The Four Modernizations, May.

Reynolds, Bruce (ed.) (1987), Reform in China: Challenges and Choices, M.E. Sharpe, New York.

Riskin, C. (1971), "Small Industry and the Chinese Model of Development," China Quarterly, 46, $245-73$.

Riskin, Carl (1987), China's Political Economy: The Quest for Development Since 1949, Studies of the East Asian Institute of Columbia University, Oxford University Press, 1987.

Roland, Gerard (2000), Politics, Markets and Firms: Transition and Economics, Cambridge, MA, MIT Press.

Ronnas, Per, (1993), "Township Enterprises in Sichuan and Zhejiang: Establishment and Capital Generation," National Workshop on Rural Industrialization in Post-Reform China, Beijing, China, October.

Sachs, J. (1993): Poland's Jump to the Market Economy. Cambridge, MA, MIT.

Sachs, J. (1994), "Notes on the Life Cycle of State-led Industrialization," Japan and World Economy, 8, 153-74.

Sachs, J. and Pistor, K. (1997), "Introduction: Progress, Pitfalls, Scenarios, and Lost Opportunities," in J. Sachs and K. Pistor eds. The Rule of Law and Economic Reform in Russia, Westview Press.

Sachs, J.and Woo, W.T. (1994a) "Understanding the Reform Experiences of China, Eastern Europe and Russia," Journal of Comparative Economics, Vol. 18, No. 3, June .

Sachs, Jeffrey, and Wing Thye Woo.(1994b), "Structural Factors in the Economic Reforms of China, Eastern Europe and the Former Soviet Union." Economic Policy, April, 18(1), pp. 102-145. 
Sachs, J. and Woo, W.T. (1999), "Understanding China's Economic Performance", Journal of Policy Reforms, forthcoming.

Sachs, J. and Yang, X. (2000), Development Economics: Inframarginal versus Marginal Analyses, Cambridge, MA, Blackwell.

Schurmann, H. (1968), Ideology and Organization in Communist China, Berkeley, University of California Press.

Shea, Jia-Dong and Ya-Hwei Yang, (1994), "Taiwan's Financial System and the Allocation of Investment Funds," in Joel Aberbach, David Dollar and Kenneth Sokoloff (ed.), The Role of State in Taiwan's Development, M.E. Sharpe, Armonk, N.Y., pp. 193-230.

Shi, H. and X. Yang (1995), "A New Theory of Industrialization", Journal of Comparative Economics, 20, 171-89.

Shleifer, A. and Vishny, R. (1992), "Pervasive Shortages Under Socialism," RAND Journal of Economics, 23, 237-46.

Shleifer, A. and Vishny, R. (1993), "The Politics of Market Socialism," Working Paper, Department of Economics, Harvard University.

Shleifer, Andrei (1998), "State versus Private Ownership," Journal of Economic Perspectives, 12, 13350 .

Skousen, Mark (1997), "The Perseverance of Paul Samuelson's Economics." Journal Economic Perspective, 11, 137-53

Solinger, D. (1992), "Urban Entrepreneurs and the State: The Merger of State and Society," pp. 121-42 in State and Society in China: The Consequences of Reform, edited by A. Rosenbaum. Boulder, Westview Press.

Taylower, George (1932), "Wholesale Commodity Prices at Charleston, South Carolina, 1732-1792", Journal of Economic and Business History, 4, 367.

Vogel, E. (1989), One Step Ahead in China: Guangdong Under Reform, Cambridge, Harvard University Press.

Walder, A. (1986), "The Informal Dimension of Enterprise Financial Reforms", pp. 630-45 in The Chinese Economy Toward the Year 2000, Joint Economic Committee, U.S. Congress. Washington D.C., U.S. Government Printing Office.

Walder, A. (1989), "Factory and Manager in an Era of Reform", The China Quarterly, No. 118, June pp. 242-264.

Walder, A. (1992), "Local Bargaining Relationships and Urban Industrial Finance," pp. 308-33 in Bureaucracy, Politics, and Decision Making in Post Mao China, edited by K. Lieberthal and D. Lampton, Berkeley, University of California Press.

Walder, Andrew. (1995), "China's Transitional Economy: Interpreting its Significance." China Quarterly, December, 144, pp. 963-979.

Wang, J. (1992), "The Third Way of the Chinese Economic Reform: Establish an Institution of Competition. The Chinese Intellectual, 7, 8-24.

Wank, D. (1993), From State Socialism to Community Capitalism: State Power, Social Structure, and Private Enterprise in a Chinese City, Unpublished Ph. Dissertation, Department of Sociology, Harvard University.

Weitzman, Martin; and Chenggang Xu. (1994), "Chinese Township Village Enterprises as Vaguely Defined Cooperatives." Journal of Comparative Economics, September, 18, pp. 121-145.

Wen, Ming (1999), Report on China's Property Owners (Zhongguo Youchanzhe Baogao), Beijing, China United Business Press.

Wong, C. (1985), "Material Allocation and Decentralization: Impact of the Local Sector on Industrial Reform," in The Political Economy of Reform in Post Mao China, edited by E. Perry and C. Wong, Cambridge, Harvard University Press.

Wong, C. (1986a), "The Economics of Shortage and Problems of Reform in Chinese Industry", Journal of Comparative Economics, 10, 363-87.

Wong, C. (1986b), "Ownership and Control in Chinese Industry: The Maoist Legacy and Prospects for the 1980s", pp. 571-602 in The Chinese Economy Toward the Year 2000, Joint Economic Committee, U.S. Congress. Washington D.C., U.S. Government Printing Office.

Woo, Wing Thye; Wen Hai; Yibiao Jin; and Gang Fan. (1994),"How Successful Has the Chinese Enterprise Reform Been?" Journal of Comparative Economics, June, 18(3), pp. 410-37.

Woodward, C. (1951), Origins of the New South, 1877-1913. New York,

World Bank (1984) World Development Report, Various issues, Washington, DC, World Bank.

Wu, Jieh-min (1998), Local Property Rights Regime in Socialist Reform: A Case Study of China's Informal Privatization. Ph. D. Dissertation, Department of Political Science, Columbia University. 
von Mises, L. (1922), Socialism: An Economic and Sociological Analysis, Indianapolis: Liberty Classics, reprinted in 1981.

Xing, Yujing (1999), "Renminbi Ziben Xiangmo Keduihuan (Is Liberalization of Capital Account of China Urgent)", Economic Highlights, No. 38, p. 2.

Yang, X. (1994), "Endogenous vs. Exogenous Comparative Advantages and Economies of Specialization vs. Economies of Scale", Journal of Economics, 60, 29-54.

Yang, X. (1998). Dangdai Jingjixue He Zhongguo Jingji (Contemporary Economics and Chinese Economy), Beijing, Publishing House of China's Social Sciences.

Yang, X. and Ng, Y-K. (1993): Specialization and Economic Organization, a New Classical Microeconomic Framework, Amsterdam, North-Holland.

Yang, X. and Ng, Y-K. (1995): "Theory of the Firm and Structure of Residual Rights", Journal of Economic Behavior and Organization, 26, 107-28.

Yang, X. and Rice, R. (1994): "An Equilibrium Model Endogenizing the Emergence of a Dual Structure between the Urban and Rural Sectors", Journal of Urban Economics, Vol. 25, 346-68.

Yang, X. and Shi, H. (1992), "Specialization and Product Diversity," American Economic Review, 82, 392-98.

Yang, X., Wang, J., and Wills, I. (1992), "Economic Growth, Commercialization, and Institutional Changes in Rural China, 1979-1987", China Economic Review, 3, 1-37.

Yi, Gang (1988), "The Efficiency of the Market and the Delimiting of Property Rights," China: Development and Reform, No 12, Beijing.

Young, Alwyn (1998) "Growth without Scale Effects," Journal of Political Economy, 106, 41-63. Zaleski, E. (1980), Stalinist Planning for Economic Growth, 1933-1952, University of North Carolina Press.

Zhang, Gang (1993), "Government Intervention versus Marketisation in China's Rural Industries: The Role of Local Governments," National Workshop on Rural Industrialization in Post-Reform China, Beijing, China, October.

Zhang, Weiying (1999), The Theory of the Firm and China's Enterprise Reforms (Qiye Lilun Yu Zhongguo Qiye Gaige). Peking University Press. See also Zhang, W. (1986), Research Report on Economic System Reforms, No. 30.

Zhou, Taihe (1984), ed., Dangdai Zhongguo de Jingji Tizhi Gaige (Economic System Reforms in Contemporary China). Beijing: China Social Science Press.

Zhou, Qiren (1999), "Ba Chuangye Huangdao Diyiwei Lai, Ba Jiuye Huangdao Dierwei Qu (Put Founding Firms before Finding Jobs)", Economic Highlights, No. 37, p. 1.

Zhuravskaya, Ekaterina. (1998), "Incentives to Provide Local Public Goods: Fiscal Federalism, Russian Style."Mimeo, Harvard University.

Zweig, David. (1991), "Rural Industry: Constraining the Leading Growth Sector in China's Economy," Joint Economic Committee, U.S. Congress, China's Economics Dilemmas in the 1990s: The Problems of Reforms, Modernization, and Interdependence, April. 